for conservation globally

Threatened

通
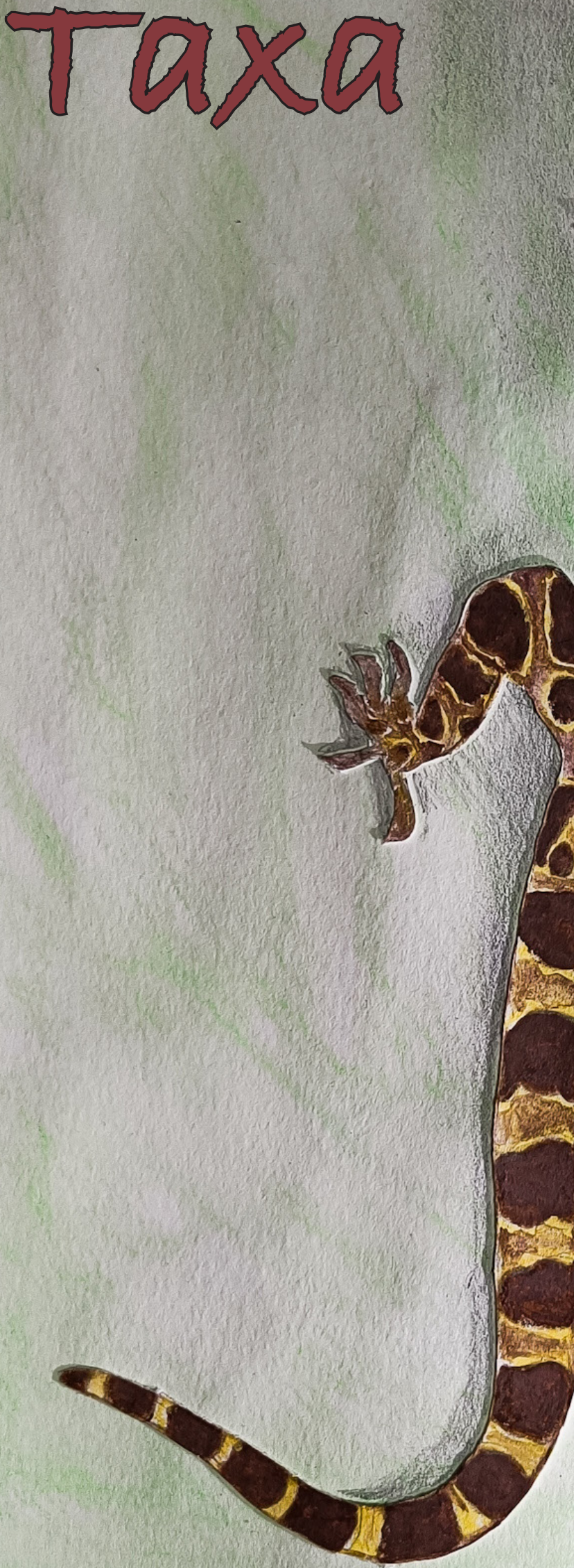

Open Access

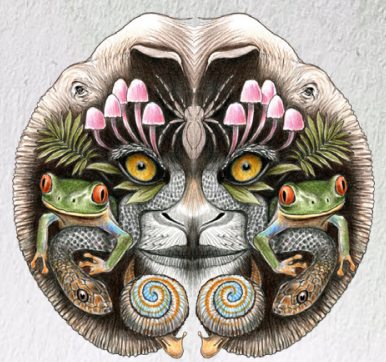

$10.1160 \mathrm{~g} / \mathrm{j}$ ott.2022.14.1.20311-20538 wWw.threatenedtaxa.org

26 January 2022 (Online \& Print) 14(1): 20311-20538 ISSN0974-7907 (Online) ISSN 0974-7893 (Print) 


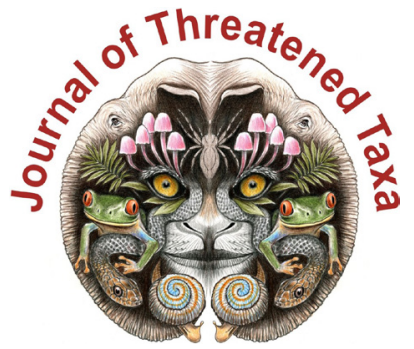

ISSN 0974-7907 (Online); ISSN $0974-7893$ (Print)

Publisher

Host

Wildlife Information Liaison Development Society

www.wild.zooreach.org

Zoo Outreach Organization www.zooreach.org

No. 12, Thiruvannamalai Nagar, Saravanampatti - Kalapatti Road, Saravanampatti, Coimbatore, Tamil Nadu 641035, India

Ph: +91 9385339863 | www.threatenedtaxa.org

Email: sanjay@threatenedtaxa.org

EDITORS

\section{Founder \& Chief Editor}

Dr. Sanjay Molur

Wildlife Information Liaison Development (WILD) Society \& Zoo Outreach Organization (ZOO),

12 Thiruvannamalai Nagar, Saravanampatti, Coimbatore, Tamil Nadu 641035, India

\section{Deputy Chief Editor}

Dr. Neelesh Dahanukar

Noida, Uttar Pradesh, India

\section{Managing Editor}

Mr. B. Ravichandran, WILD/ZOO, Coimbatore, India

\section{Associate Editors}

Dr. Mandar Paingankar, Government Science College Gadchiroli, Maharashtra 442605, India

Dr. Ulrike Streicher, Wildlife Veterinarian, Eugene, Oregon, USA

Ms. Priyanka Iyer, ZOO/WILD, Coimbatore, Tamil Nadu 641035, India

Dr. B.A. Daniel, ZOO/WILD, Coimbatore, Tamil Nadu 641035, India

\section{Editorial Board}

Dr. Russel Mittermeier

Executive Vice Chair, Conservation International, Arlington, Virginia 22202, USA

\section{Prof. Mewa Singh Ph.D., FASc, FNA, FNASc, FNAPsy}

Ramanna Fellow and Life-Long Distinguished Professor, Biopsychology Laboratory, and Institute of Excellence, University of Mysore, Mysuru, Karnataka 570006, India; Honorary Professor, Jawaharlal Nehru Centre for Advanced Scientific Research, Bangalore; and Adjunct Professor, National Institute of Advanced Studies, Bangalore

\section{Stephen D. Nash}

Scientific Illustrator, Conservation International, Dept. of Anatomical Sciences, Health Sciences Center, T-8, Room 045, Stony Brook University, Stony Brook, NY 11794-8081, USA

\section{Dr. Fred Pluthero}

Toronto, Canada

\section{Dr. Priya Davidar}

Sigur Nature Trust, Chadapatti, Mavinhalla PO, Nilgiris, Tamil Nadu 643223, India

\section{Dr. Martin Fisher}

Senior Associate Professor, Battcock Centre for Experimental Astrophysics, Cavendish

Laboratory, JJ Thomson Avenue, Cambridge CB3 OHE, UK

\section{Dr. John Fellowes}

Honorary Assistant Professor, The Kadoorie Institute, 8/F, T.T. Tsui Building, The University of Hong Kong, Pokfulam Road, Hong Kong

\section{Prof. Dr. Mirco Solé}

Universidade Estadual de Santa Cruz, Departamento de Ciências Biológicas, Vice-coordenado do Programa de Pós-Graduação em Zoologia, Rodovia Ilhéus/Itabuna, Km 16 (45662-000)

Salobrinho, Ilhéus - Bahia - Brasil

\section{Dr. Rajeev Raghavan}

Professor of Taxonomy, Kerala University of Fisheries \& Ocean Studies, Kochi, Kerala, India

\section{English Editors}

Mrs. Mira Bhojwani, Pune, India

Dr. Fred Pluthero, Toronto, Canad

Mr. P. Ilangovan, Chennai, India

Web Development

Mrs. Latha G. Ravikumar, ZOO/WILD, Coimbatore, India

\section{Typesetting}

Mr. Arul Jagadish, ZOO, Coimbatore, India

Mrs. Radhika, ZOO, Coimbatore, India

Mrs. Geetha, ZOO, Coimbatore India
Fundraising/Communications

Mrs. Payal B. Molur, Coimbatore, India

Subject Editors 2018-2020

Fungi

Dr. B. Shivaraju, Bengaluru, Karnataka, India

Dr. R.K. Verma, Tropical Forest Research Institute, Jabalpur, India

Dr. Vatsavaya S. Raju, Kakatiay University, Warangal, Andhra Pradesh, India

Dr. M. Krishnappa, Jnana Sahyadri, Kuvempu University, Shimoga, Karnataka, India

Dr. K.R. Sridhar, Mangalore University, Mangalagangotri, Mangalore, Karnataka, India

Dr. Gunjan Biswas, Vidyasagar University, Midnapore, West Bengal, India

\section{Plants}

Dr. G.P. Sinha, Botanical Survey of India, Allahabad, India

Dr. N.P. Balakrishnan, Ret. Joint Director, BSI, Coimbatore, India

Dr. Shonil Bhagwat, Open University and University of Oxford, UK

Prof. D.J. Bhat, Retd. Professor, Goa University, Goa, India

Dr. Ferdinando Boero, Università del Salento, Lecce, Italy

Dr. Dale R. Calder, Royal Ontaro Museum, Toronto, Ontario, Canada

Dr. Cleofas Cervancia, Univ. of Philippines Los Baños College Laguna, Philippines

Dr. F.B. Vincent Florens, University of Mauritius, Mauritius

Dr. Merlin Franco, Curtin University, Malaysia

Dr. V. Irudayaraj, St. Xavier's College, Palayamkottai, Tamil Nadu, India

Dr. B.S. Kholia, Botanical Survey of India, Gangtok, Sikkim, India

Dr. Pankaj Kumar, Kadoorie Farm and Botanic Garden Corporation, Hong Kong S.A.R., China

Dr. V. Sampath Kumar, Botanical Survey of India, Howrah, West Bengal, India

Dr. A.J. Solomon Raju, Andhra University, Visakhapatnam, India

Dr. Vijayasankar Raman, University of Mississippi, USA

Dr. B. Ravi Prasad Rao, Sri Krishnadevaraya University, Anantpur, India

Dr. K. Ravikumar, FRLHT, Bengaluru, Karnataka, India

Dr. Aparna Watve, Pune, Maharashtra, India

Dr. Qiang Liu, Xishuangbanna Tropical Botanical Garden, Yunnan, China

Dr. Noor Azhar Mohamed Shazili, Universiti Malaysia Terengganu, Kuala Terengganu, Malaysia

Dr. M.K. Vasudeva Rao, Shiv Ranjani Housing Society, Pune, Maharashtra, India

Prof. A.J. Solomon Raju, Andhra University, Visakhapatnam, India

Dr. Mandar Datar, Agharkar Research Institute, Pune, Maharashtra, India

Dr. M.K. Janarthanam, Goa University, Goa, India

Dr. K. Karthigeyan, Botanical Survey of India, India

Dr. Errol Vela, University of Montpellier, Montpellier, France

Dr. P. Lakshminarasimhan, Botanical Survey of India, Howrah, India

Dr. Larry R. Noblick, Montgomery Botanical Center, Miami, USA

Dr. K. Haridasan, Pallavur, Palakkad District, Kerala, India

Dr. Analinda Manila-Fajard, University of the Philippines Los Banos, Laguna, Philippines

Dr. P.A. Sinu, Central University of Kerala, Kasaragod, Kerala, India

Dr. Afroz Alam, Banasthali Vidyapith (accredited A grade by NAAC), Rajasthan, India

Dr. K.P. Rajesh, Zamorin's Guruvayurappan College, GA College PO, Kozhikode, Kerala, India

Dr. David E. Boufford, Harvard University Herbaria, Cambridge, MA 02138-2020, USA

Dr. Ritesh Kumar Choudhary, Agharkar Research Institute, Pune, Maharashtra, India

Dr. Navendu Page, Wildlife Institute of India, Chandrabani, Dehradun, Uttarakhand, India

\section{Invertebrates}

Dr. R.K. Avasthi, Rohtak University, Haryana, India

Dr. D.B. Bastawade, Maharashtra, India

Dr. Partha Pratim Bhattacharjee, Tripura University, Suryamaninagar, India

Dr. Kailash Chandra, Zoological Survey of India, Jabalpur, Madhya Pradesh, India

Dr. Ansie Dippenaar-Schoeman, University of Pretoria, Queenswood, South Africa

Dr. Rory Dow, National Museum of natural History Naturalis, The Netherlands

Dr. Brian Fisher, California Academy of Sciences, USA

Dr. Richard Gallon, llandudno, North Wales, LL30 1UP

Dr. Hemant V. Ghate, Modern College, Pune, India

Dr. M. Monwar Hossain, Jahangirnagar University, Dhaka, Bangladesh

Mr. Jatishwor Singh Irungbam, Biology Centre CAS, Branišovská, Czech Republic.

Dr. Ian J. Kitching, Natural History Museum, Cromwell Road, UK

Dr. George Mathew, Kerala Forest Research Institute, Peechi, India

For Focus, Scope, Aims, and Policies, visit https://threatenedtaxa.org/index.php/JoTT/aims_scope
For Article Submission Guidelines, visit https://threatenedtaxa.org/index.php/JoTT/about/submissions
For Policies against Scientific Misconduct, visit https://threatenedtaxa.org/index.php/JoTT/policies_various

continued on the back inside cover 


\title{
Local hunting practices and perceptions regarding the distribution and ecological role of the Large Flying Fox (Chiroptera: Pteropodidae: Pteropus vampyrus) in western Sarawak, Malaysian Borneo
}

\author{
Jayasilan Mohd-Azlan ${ }^{1} \mathbb{D}$, Joon Yee Yong ${ }^{2} \mathbb{D}$, Nabila Norshuhadah Mohd Hazzrol ${ }^{3} \mathbb{D}$, \\ Philovenny Pengiran ${ }^{4}\left(\mathbb{D}\right.$, Arianti Atong ${ }^{5}$ (D) \& Sheema Abdul Aziz ${ }^{6}$ (D)
}

\footnotetext{
1,3,4 Institute of Biodiversity and Environmental Conservation, Universiti Malaysia Sarawak, 94300 Kota Samarahan, Sarawak, Malaysia. 2,6 Project Pteropus, Rimba, 22-3A Casa Kiara 2, Jalan Kiara 5, 50480 Kuala Lumpur, Malaysia. ${ }_{5}^{5}$ Sarawak Forestry Corporation Sdn. Bhd., Lot 218, KCLD, Jalan Tapang, Kota Sentosa, 93250, Kuching, Sarawak, Malaysia. ${ }^{1}$ azlan@unimas.my, ${ }^{2}$ joonyee@rimbaresearch.org, ${ }^{3}$ nabila.mhazzy@gmail.com, ${ }^{4}$ philovennypengiran26@gmail.com, ${ }^{5}$ arianti@sarawakforestry.com, ${ }^{6}$ sheema@rimbaresearch.org (corresponding author)
}

\begin{abstract}
Pteropodids such as flying foxes are declining rapidly across their range due to human activities, despite their benefit to humans through ecosystem services. The Large Flying Fox Pteropus vampyrus had a wide distribution across Borneo, but is now severely reduced in numbers, and rarely sighted. In order to develop effective conservation and management prescriptions for this species, updated information on its distribution, movement patterns, and the impact of anthropogenic pressure on its survival is crucial. As such, a questionnaire survey was conducted in western Sarawak to determine the occurrence of this species, and the conservation awareness for the species amongst local communities. The survey was conducted at nine sites during November 2018 - March 2019, involving a total of 123 respondents, including hunters $(20 \%)$ and consumers $(35 \%)$ of $P$. vampyrus. Respondents reported that $P$. vampyrus appears sporadically around the western tip of Borneo, and around the interior parts of western Sarawak, with more than half $(51 \%)$ of the reported sightings in the interior occurring at fruit orchards during the fruiting and flowering seasons. Despite hunting and consuming this species, over $60 \%$ of the respondents felt that $P$. vampyrus could become an eco-tourism product in their area. Although many respondents viewed flying foxes as pests (47\%) or food (52\%), there was remarkably high awareness of the ecological roles and conservation needs of this species (76\%), suggesting potentially strong support for flying fox conservation at the local level. Challenges associated with the enforcement of wildlife law in the remote parts of Sarawak need to be addressed, alongside strategic education and awareness efforts, which are all vital to achieve successful conservation and protection of this ecologically important species.
\end{abstract}

Keywords: Bats, conservation, indigenous, local communities, Malaysia, Palaeotropics, wildlife.

Citation: Mohd-Azlan, J., J.Y. Yong, N.N.M. Hazzrol, P. Pengiran, A. Atong \& S.A. Aziz (2022). Local hunting practices and perceptions regarding the distribution and ecological role of the Large Flying Fox (Chiroptera: Pteropodidae: Pteropus vampyrus) in western Sarawak, Malaysian Borneo. Journal of Threatened Taxa 14(1): 20387-20399. https://doi.org/10.11609/jott.6977.14.1.20387-20399

Copyright: (c) Mohd-Azlan et al. 2022. Creative Commons Attribution 4.0 International License. JoTT allows unrestricted use, reproduction, and distribution of this article in any medium by providing adequate credit to the author(s) and the source of publication.

Funding: (a) United States Fish and Wildlife Service (USFWS; F17AP00829); (b) Malaysian Ministry of Higher Education - Fundamental Research Grant Scheme (FRGS/1/2020/WAB11/UNIMAS/02/3)

Competing interests: The authors declare no competing interests.

Author details, Author contributions and Acknowledgements: See end of this article.
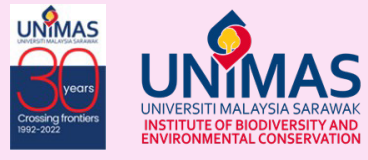

INSITUTE OF BIODIVERSITYAND
INVIRONMENTAL CONSERVATION

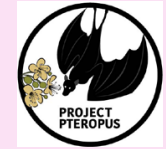

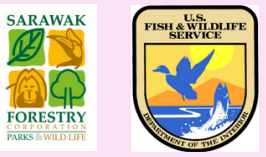

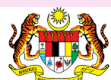

MINISTRY OF HIGHER EDUCATION 


\section{INTRODUCTION}

Despite providing crucial ecosystem services such as seed dispersal and pollination, populations of Old World fruit bats (Chiroptera: Pteropodidae) are rapidly decreasing across their range due to multiple anthropogenic threats (Fujita \& Tuttle 1991; Kunz et al. 2011; Aziz et al. 2021). In Southeast Asia, pteropodids have been well-documented as critical pollinators of the economically important durian (Durio zibethinus) fruit, which is worth millions of USD to the economies of producing countries (Bumrungsri et al. 2009; Aziz et al. 2017a: Sheherazade et al. 2019). Despite these benefits, pteropodid bats, especially flying foxes (Pteropus spp., Acerodon spp., Desmalopex spp.), have been widely hunted for food and medicinal purposes in many AsiaPacific cultures (Mildenstein et al. 2016; Low et al. 2021). Additionally, they are also persecuted and culled as fruit crop pests throughout their range (Aziz et al. 2016).

Pteropus vampyrus, the Large Flying Fox, is distributed throughout much of mainland and insular Southeast Asia (Bates et al. 2008). It is the largest bat found on Borneo, and is also the only known flying fox species found in Sarawak (Aziz et al. 2019). Like other pteropodids, this species plays a critical role in pollination and seed dispersal (Gould 1997; Gumal 2001; Mohd-Azlan et al. 2001; McConkey \& Drake 2006; Aziz et al. 2017a). Although this species is under threat and legally protected in Sarawak under the Sarawak Wild Life Protection Ordinance 1998, it is listed as only Near Threatened on the global IUCN Red List, despite a decreasing trend noted for its global population (Bates et al. 2008) which is still being hunted/traded as a delicacy and for its perceived medicinal qualities (Fujita \& Tuttle 1991; Mildenstein et al. 2016; Low et al. 2021). In general, most communities across Borneo share the belief that consumption of flying fox meat and liver is a cure for general malaise and respiratory ailments (Fujita 1988; Mohd-Azlan \& Fauzi 2006; Low et al. 2021).

Like many other fruit bats in Southeast Asia, $P$. vampyrus is at high risk of becoming extinct by the end of the century, not only due to intense hunting pressure (Epstein et al. 2009) but also due to high deforestation rates across the region (Lane et al. 2006). In Sarawak, the last state-wide survey on $P$. vampyrus roosting sites was conducted during 1997-2000, and only five maternity colonies were found: in Patok Island, Sarang, Loagan Bunut, Limbang, and Sedilu (Gumal 2001). Therefore, for the conservation management of this species in Sarawak, more recent data on its distribution and status are urgently needed.
In addition to its outdated distribution and population data in Sarawak, little is known about local community perceptions, knowledge, and awareness of $P$. vampyrus, as no prior studies have been conducted on these aspects. Hence, as community-based wildlife surveys are known to be an effective tool to help elucidate the distribution of wildlife species and their interactions with humans (Fitzgibbon \& Jones 2006), we employed this approach in western Sarawak to obtain information on $P$. vampyrus, namely: (i) the current distribution patterns; (ii) hunting and consumption by local communities; and (iii) their perception of the ecological role of this species.

\section{MATERIALS AND METHODS}

\section{Study Site}

Sarawak, Malaysia $\left(1.553278^{\circ}, 110.359213^{\circ}\right.$; Figure 1) is located in northwestern Borneo and has a population of $\sim 2.8$ million (Department of Statistics Malaysia 2019). Sixty-two percent of the state is still forested, with peat swamp forests dominating the coastal lowlands to hill dipterocarp forests towards the interior, and montane forests in the interior highlands (Forest Department of Sarawak 2020). The climate is uniformly humid and warm throughout the year, with the north-east monsoon occurring during NovemberFebruary, and the south-west monsoon occurring during June-October (Hazebroek \& Abang Kashim 2000).

Approximately $29 \%$ of Sarawak's population belongs to the Iban indigenous group making up the majority, followed by $23 \%$ of ethnic Malays, Chinese (22\%), Bidayuh (8\%), Melanau (5\%), other indigenous groups $(6 \%)$, other non-indigenous groups (1\%), and lastly, non-Malaysian citizens make up $6 \%$ of the population (Department of Statistics Malaysia 2019). Christianity is the most professed religion in Sarawak (43\%), followed by Islam (32\%), Buddhism (13\%), Confucianism, Taoism, and Tribal religions (6\%), Hinduism $(0.2 \%)$, others (1\%), no religion (3\%), and unknown religion (2\%) (Department of Statistics Malaysia 2010). Ethnic Malays do not hunt bats for consumption due to Islamic dietary restrictions, but may still kill fruit bats for fruit crop protection (Aziz et al. 2017b), or for sale to non-Muslims (Low et al. 2021).

Our survey was conducted at nine sites in western Sarawak: Sri Aman, LubokAntu, Lubok Subong, Maludam, Sebuyau, Sematan, Simunjan, Serian, and Tanjung Manis (Figure 1). These locations were selected based on previous information on markets where flying foxes were sold (Gumal et al. 1997), and our own preliminary enquiries regarding popular sites for bushmeat trading. 


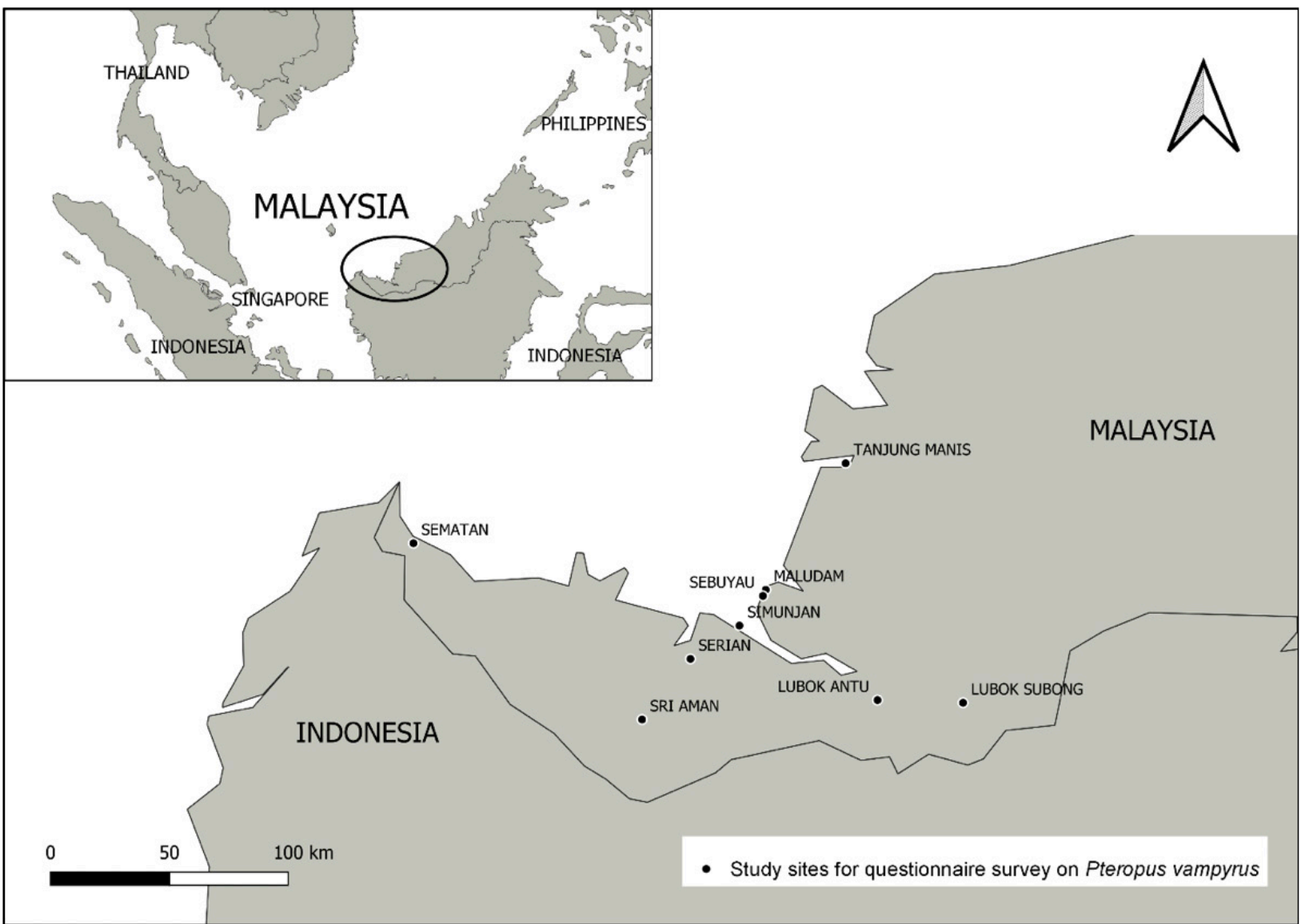

Figure 1. Study sites in western Sarawak, Malaysian Borneo (Generated by QGIS 3.6).

\section{Study Species}

Pteropus vampyrus is one of the largest bats in the world, weighing up to $1.1 \mathrm{~kg}$ and with a wingspan of up to $1.5 \mathrm{~m}$ (Image 1). It is listed as 'Near Threatened' on the IUCN Red List (Bates et al. 2008), although there appears to be a sharp population decline in Sarawak (Gumal 2001), and in Peninsular Malaysia due to overharvesting (Epstein et al. 2009). It is listed as Endangered on the Red List of Mammals for Peninsular Malaysia (PERHILITAN 2017). In Sarawak all bat species including $P$. vampyrus are protected under the Wild Life Protection Ordinance 1998, and hunting is not allowed.

Currently, little is known about the population and distribution of $P$. vampyrus in Sarawak, as the last statewide survey was conducted by Gumal (2001) around two decades ago. That survey found that all five of the reported roosts were located in remote and inaccessible areas such as peat swamps and mangroves.

\section{Data Collection}

A questionnaire survey (Table 1 ) consisting of openended and closed questions was designed to obtain data on (1) local community socio-demographics; (2) $P$. vampyrus sightings; (3) consumption and hunting of this species by local communities; and (4) local community perceptions of the species. A pilot survey was first conducted on 35 individuals comprising members of the general public and students from Universiti Malaysia Sarawak (UNIMAS) in Kota Samarahan.

The questionnaire survey was conducted during November 2018-March 2019, at local markets in the nine study sites. Respondents were surveyed opportunistically using snowball sampling, starting first with a durian vendor who then recommended other people known to hunt or consume flying foxes (Image 2). Respondents were then selected based on preliminary questioning to ascertain whether they were: (i) familiar with P. vampyrus; (ii) hunters; or (iii) consumers of the species.

Before the questionnaire commenced the respondents were first asked to identify $P$. vampyrus by displaying an image of the species with a corresponding measurement scale to convey size, and this was used to set the benchmark for the reliability of the respondents' 
Table 1. Questionnaire used for survey on community knowledge, perceptions and interactions with Pteropus vampyrus (referred to as simply 'flying fox' in local languages during interviews) in western Sarawak.

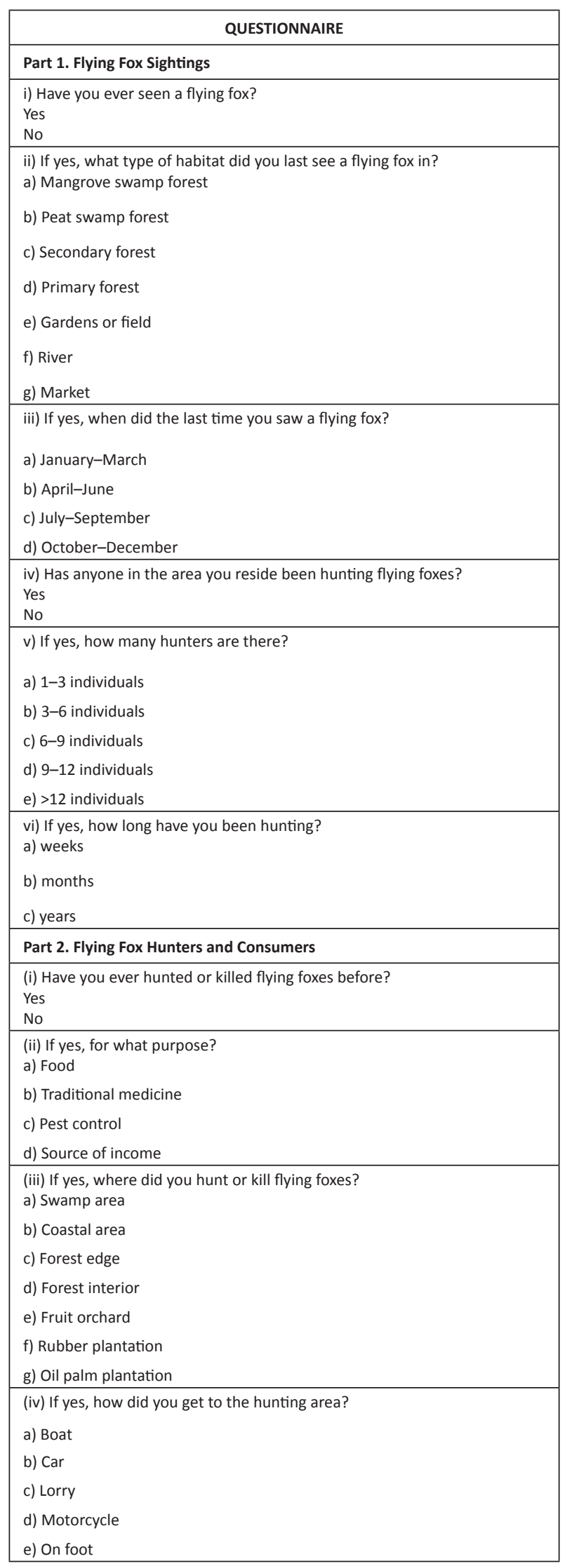

\begin{tabular}{|c|}
\hline $\begin{array}{l}\text { (v) What method do you use to hunt flying foxes? } \\
\text { a) Net } \\
\text { b) Shotgun } \\
\text { c) Traditional method (stringing up hooks on fishing line) } \\
\text { d) Cutting down roost tree }\end{array}$ \\
\hline $\begin{array}{l}\text { (vi) At what time do you usually hunt flying foxes? } \\
\text { a) } 0600 \mathrm{hrs}-0900 \mathrm{hrs} \\
\text { b) } 0900 \mathrm{hrs}-1200 \mathrm{hrs} \\
\text { c) } 1200 \mathrm{hrs}-1500 \mathrm{hrs} \\
\text { d) } 1500 \mathrm{hrs}-1800 \mathrm{hrs} \\
\text { e) } 1800 \mathrm{hrs}-2100 \mathrm{hrs} \\
\text { f) } 2100 \mathrm{hrs}-0000 \mathrm{hrs} \\
\text { g) } 0000 \mathrm{hrs}-0300 \mathrm{hrs} \\
\text { h) } 0300 \mathrm{hrs}-0600 \mathrm{hrs}\end{array}$ \\
\hline $\begin{array}{l}\text { (vii) On average, how much is the total cost of a flying fox hunting trip? } \\
\text { a) <RM50 } \\
\text { b) RM51-RM100 } \\
\text { c) RM101-RM300 } \\
\text { d) RM301-RM600 }\end{array}$ \\
\hline
\end{tabular}

(viii) On average, how many flying foxes do you catch per hunting trip?

a) $<10$ individuals

b) $11-20$ individuals

c) 21-40 individuals

d) 41-60 individuals

e) 61-80 individuals

f) $>80$ individuals

(ix) On average, what is the market price of flying fox meat?

$$
\begin{aligned}
& \text { a) RM10-RM15 } \\
& \text { b) RM16-RM30 } \\
& \text { c) RM31-RM60 } \\
& \text { d) RM61-RM80 } \\
& \text { e) RM81-RM100 } \\
& \text { f) RM100-RM120 }
\end{aligned}
$$

(x) What motivates you to hunt?

(xi) Do you get moral support from your local community to hunt flying foxes?

Yes

No

(xii) How does the local community in the area you reside feel about you hunting flying foxes?

(xiii) Have you ever consumed or cooked flying fox meat? Yes

(xiv) If yes, how did you process the meat?

(xv) If yes, what other ingredients did you mix with the flying fox meat?

(xvi) Which parts of a flying fox are used as traditional medicine? 


\begin{tabular}{|c|c|c|c|c|c|}
\hline \multicolumn{6}{|l|}{ Part 3. Local perceptions towards flying foxes } \\
\hline Statements & $\begin{array}{l}\text { Strongly } \\
\text { Agree }\end{array}$ & Agree & Not Sure & Disagree & $\begin{array}{l}\text { Strongly } \\
\text { Disagree }\end{array}$ \\
\hline \multicolumn{6}{|l|}{ Occasionally consuming flying fox meat is fine. } \\
\hline \multicolumn{6}{|l|}{ Consuming flying fox meat can cure respiratory ailments. } \\
\hline \multicolumn{6}{|l|}{ Flying foxes can damage agricultural crops. } \\
\hline \multicolumn{6}{|l|}{$\begin{array}{l}\text { Hunting \& selling flying foxes can damage their populations in the } \\
\text { long term. }\end{array}$} \\
\hline \multicolumn{6}{|c|}{$\begin{array}{l}\text { Deforestation causes more negative impacts on flying fox populations } \\
\text { compared to hunting activities. }\end{array}$} \\
\hline \multicolumn{6}{|l|}{ Sarawak's wildlife law has been effective in protecting flying foxes. } \\
\hline \multicolumn{6}{|l|}{ Flying foxes can be an important aspect in promoting tourism. } \\
\hline \multicolumn{6}{|l|}{ Flying foxes play an important role in dispersing seeds. } \\
\hline \multicolumn{6}{|l|}{$\begin{array}{l}\text { Awareness programs in schools will help to increase efforts to } \\
\text { conserve flying foxes. }\end{array}$} \\
\hline \multicolumn{6}{|l|}{$\begin{array}{l}\text { Besides the Sarawak wildlife law, flying foxes also need to be } \\
\text { protected at the village level. }\end{array}$} \\
\hline There are traditional beliefs or taboos related to flying foxes. & & & & & \\
\hline
\end{tabular}

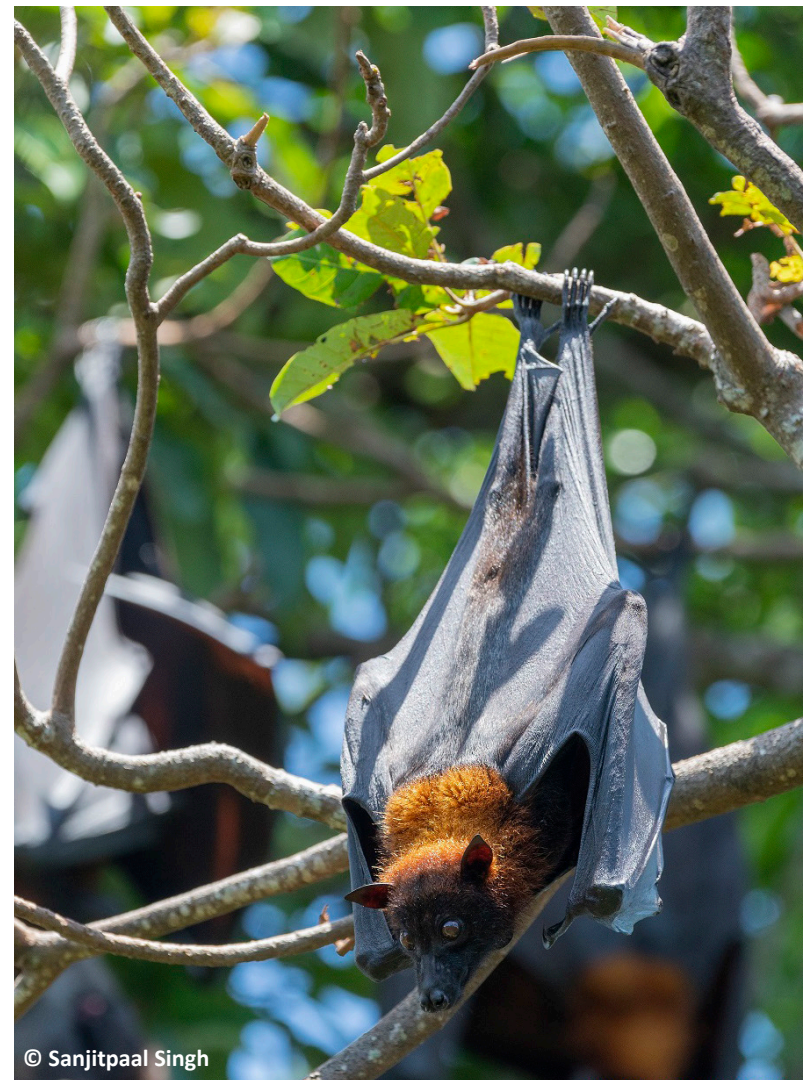

Image 1. Pteropus vampyrus roosting in Peninsular Malaysia.

answers. As flying foxes (Pteropus spp., Acerodon spp., Desmalopex spp.) often have specific local names to distinguish them from all other bats (e.g., Tanalgo et al. 2016; Low et al. 2021), wherever applicable we used the relevant local name according to a respondent's

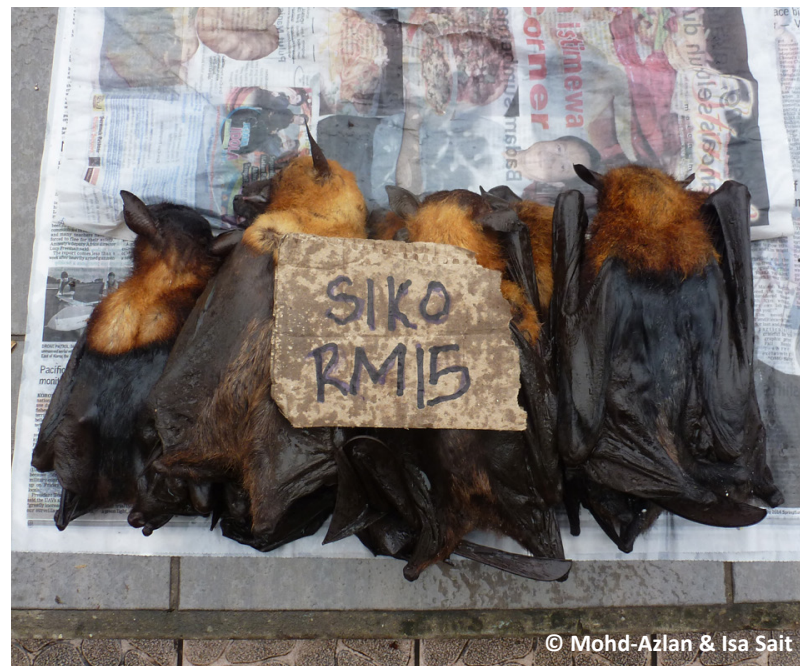

Image 2. Flying fox meat in Sarawak is considered a delicacy and perceived to have medicinal qualities.

ethnicity (Supplementary Table 1).

The questionnaire was administered by three female enumerators, who were all Malaysian students at Universiti Malaysia Sarawak (UNIMAS), via face-to-face interviews conducted in Iban, Melanau, and standard colloquial Malay. Enumerators targeted respondents that were adults, i.e., aged 18 and above. Prior to commencing an interview, the student enumerators first started with an introduction of their background, i.e., UNIMAS students conducting research on flying foxes, and also showed their university student identification cards when introducing themselves. Each question was read aloud by the enumerator to the respondent, and 
the respondent's answers were then recorded using the Open Data Kit Collection (ODK) version 1.18.0 application.

This study complies with the research ethics criteria designated by Universiti Malaysia Sarawak (UNIMAS), conducted under research permits NPW.907.4.4(JLD.14)-71 and WL043/2017. Before initiating any interview, the survey purpose and goals were explained first to the respondent, and free, prior, \& informed consent (FPIC) was obtained. Respondent identities were kept anonymous, and they were informed of the confidentiality of their identity and information shared. The respondents were also informed in advance that they have the right to choose not to continue with the interview at any time during the process should they feel uncomfortable.

\section{RESULTS}

Out of 200 people approached, 123 (40 women and 83 men; Supplementary Table 2) responded. Most of the $38.5 \%$ of people who declined to be interviewed claimed not to have any knowledge on the topic, but some appeared to be intimidated. The biggest group (43\%) of respondents was those above 55 years old $(n=53)$. The Iban ethnic group comprised half of all respondents, and $60 \%$ of respondents professed Christianity as their religion. A large majority (86\%) resided in rural areas, with $72 \%$ having received some form of formal education (i.e., school or university), and $37 \%$ having received an education beyond primary level (i.e., $>12$ years old).

Sixty-one percent of respondents were selfemployed, owning small businesses such as restaurants, food stalls or wet market stalls. Twenty-one percent were unemployed retirees from either the government or private sector. Sixty-nine percent had an income of less than MYR (Malaysian ringgit) 900 ( USD 213) a month, with their livelihoods dependent on the selling of forest products at markets.

\section{Flying fox sightings}

The majority (91\%) of respondents were familiar with Pteropus vampyrus, with $51 \%$ of respondents stating that flying foxes were most commonly found during the fruiting season. Hunters reported that Engkelili, Lingga, Entumpi, Engkalong, Roban, Kampung Temiang, and Simunjan are flying fox hotspots. Seventy-nine percent of respondents stated that the highest occurrence of flying fox sightings was in July-December, with JulySeptember being the most likely time to encounter flying

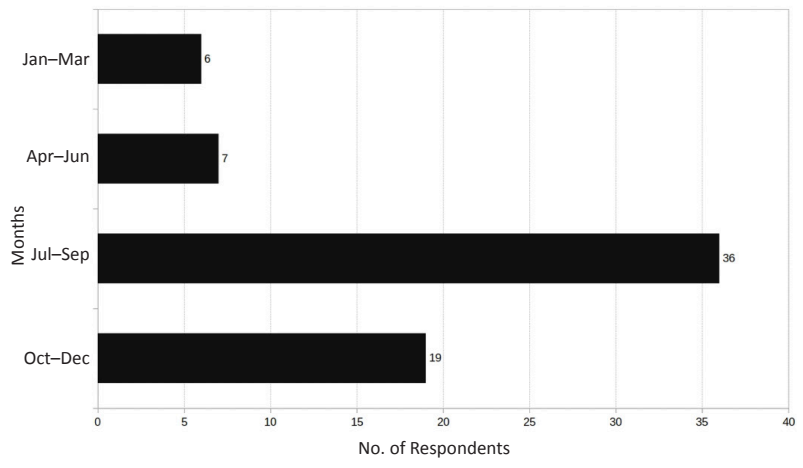

Figure 2. Time of year when $P$. vampyrus is most likely to be encountered according to respondents $(n=68)$ in western Sarawak, Malaysian Borneo.

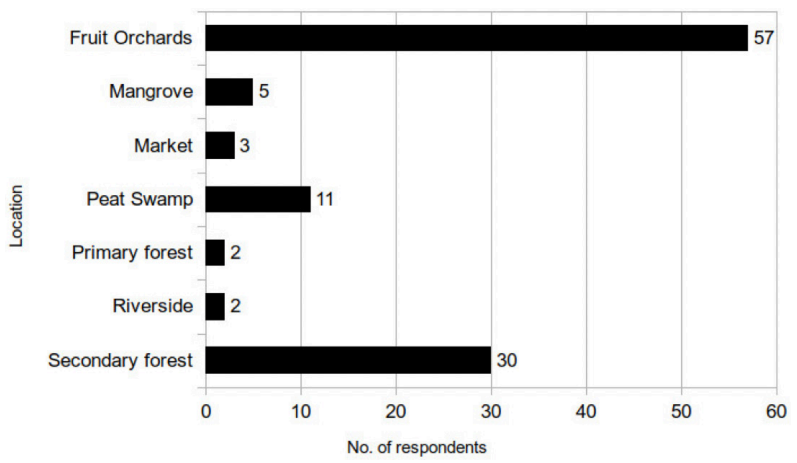

Figure 3. Habitat types where $P$. vampyrus has been sighted by respondents $(n=110)$ in western Sarawak, Malaysian Borneo.

Table 2. The reported price of $\boldsymbol{P}$. vampyrus meat at the time of last purchase by 23 respondents in western Sarawak, Malaysian Borneo.

\begin{tabular}{|c|c|c|}
\hline $\begin{array}{c}\text { Price range per bat } \\
\text { (MYR) }\end{array}$ & $\begin{array}{c}\text { Number of } \\
\text { Respondents }\end{array}$ & $\%$ \\
\hline $10-15$ & & \\
\hline $16-30$ & 7 & 30 \\
\hline $31-60$ & 15 & 4 \\
\hline
\end{tabular}

foxes (Figure 2). Fifty-nine percent of respondents stated that flying foxes forage on langsat (Lansium parasiticum), rambutan (Nephelium lappaceum), and Syzygium cephalophorum fruits, and $51 \%$ of respondents stated that flying foxes forage on durian (Durio spp.) flowers.

Fifty-two percent of respondents stated that flying foxes can be seen in fruit orchards. The species was also reported as being sighted near secondary and primary forests (Figure 3). Three respondents had sighted dead flying foxes being sold at the Pasar Tamu Sri Aman, Pasar Serian, and Pasar Lubok Antu markets. An additional $10 \%$ of respondents had sighted flying fox roosting sites, 
having seen the bats flying near mangrove and peat swamp forests in the Simunjan and Tanjung Manis areas around $20-30$ years ago.

\section{Hunting and consumption of flying foxes}

Twenty-one percent $(n=51)$ of respondents were flying fox hunters, but $53 \%$ of these hunters no longer hunted due to the difficulty of locating roosting sites (Supplementary Table 3). A slight majority (58\%) of hunters hunted flying foxes for food, while $35 \%$ hunted because flying foxes were viewed as pests, and the remainder hunted flying foxes for supplementary income. According to 15 respondents, price per bat ranged from MYR 16-30 (approximately USD 4-7) (Table 2), and even the lowest price of MYR 10 (approximately USD 2.50) was higher than the local price of chicken, which is MYR 8.50/kg (approximately USD 2/kg).

Forty-one percent of hunters preferred hunting in groups of 3-6 people, and $83 \%$ of hunters preferred hunting from dusk till midnight. Seventy-five percent of hunters stated that they hunted in fruit orchards. The most common hunting technique employed by the hunters was shooting the flying foxes with shotguns (46\%), followed by traditional hunting techniques involving hooks and strings (29\%). Many (67\%) of the hunters reported that they only managed to hunt less than 10 individuals per hunting trip.
Thirty-five percent of respondents had consumed flying foxes before, while the others (65\%) who had not, cited a variety of reasons including religious reasons $(46 \%)$, fear (38\%), and a dislike of the smell of flying foxes (16\%). Those that consumed flying foxes stated that soups and stews with an assortment of herbs and spices were the main methods ( $86 \%$ ) of cooking, whereby the fur is first removed by burning, and the animal is then skinned to eliminate its odour. The carcass (Image 2 is cleansed with either lime juice or tamarind juice to further remove any remaining odour, and the meat is then marinated with lemongrass, ginger, chilli, pepper, garlic, and onion. Some respondents claimed that the wings are a delicacy, with a chewy texture resembling the black fungus (Auricularia polytricha).

Our survey also revealed that people who bought flying fox meat preferred it to be as fresh as possible. To meet this demand, hunters string fine-meshed nets over waterways, or above/around fruit trees near their village. This method is the preferred method of Iban hunters, as it is an efficient and common method for capturing live bats to meet consumer demand for freshness. Live flying foxes trapped in the nets are harvested in the morning and brought to the market immediately to be sold, and only killed once a sale is made. Flying foxes caught by nets are sold at higher prices compared to those that are shot, as shot bats have wounds on their wings, and

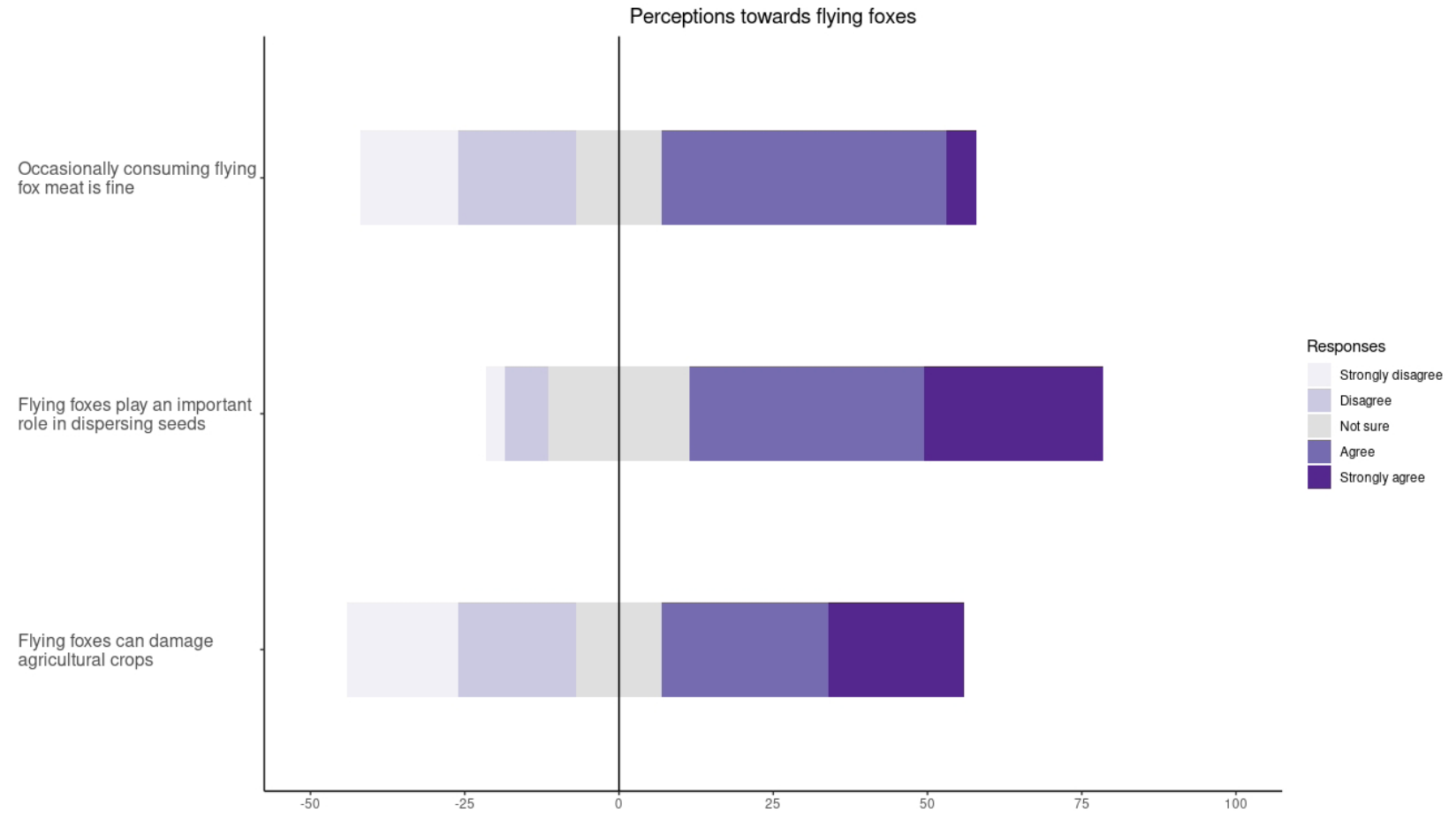

Figure 4. Perceptions of local communities towards flying foxes ( $P$. vampyrus) in western Sarawak, Malaysian Borneo ( $\mathrm{n}=120$ ). 
those that survive do not stay alive for long - thereby less desirable to consumers. However, another hunting method, considered to be more traditional, involves stringing up a fishing line tied with large fishing hooks above the canopy of a fruiting or flowering tree. As the bats get caught easily on the hooks during flight, this is sometimes used due to its ffectiveness and low cost, with one hunter reporting that as many as 30 bats could be caught from just one tree in one night using this method.

\section{Perceptions of local communities towards flying foxes}

Fifty-one percent of respondents felt that the current consumption of flying fox meat does not negatively impact flying fox populations (Figure 4), although $71 \%$ of respondents conceded that hunting and selling of flying fox meat would become a threat in the long term. Sixty-nine percent of respondents believed that deforestation is a bigger threat to flying fox populations compared to hunting. Slightly more than half (55\%) of the respondents were unsure of the claimed medicinal properties of flying foxes. For perceptions of flying foxes as agricultural pests, respondents were divided between those perceiving flying foxes to be pests (48\%), and those who did not (38\%), with the rest being unsure (14\%) (Figure 4). Despite this, $66 \%$ of the respondents were aware of the role played by flying foxes in seed dispersal (Figure 4). To prevent fruit losses, growers typically set up nets around their fruit trees so that the bats are trapped before reaching the fruits. The nets are often set up in the afternoon, and taken down late at night $(0000-0300 \mathrm{~h})$ or the following morning.

Half of all respondents felt that flying foxes could be used to develop local eco-tourism, and $51 \%$ of respondents agreed to participate in school events such as talks or seminars conducted by the relevant conservation authorities on the importance of flying foxes. Forty-four percent of respondents believed that flying fox conservation requires management at the village or local community level in order to prevent excessive hunting. Lastly, $39 \%$ of respondents felt that the Sarawak Wild Life Ordinance 1998, which makes it illegal to hunt, capture, sell, import or export bats, is ineffective at conserving flying foxes.

\section{DISCUSSION}

Our survey has provided important and novel data on the opinion and perceptions of local communities regarding Pteropus vampyrus in western Sarawak. To our knowledge, this is the first attempt to collect empirical data on the knowledge and opinions of people in Malaysian Borneo regarding this species. Our study confirmed that hunting and trade of $P$. vampyrus still occurs despite the decline in sightings, and the implementation of legal protection for this species - partly due to cultural beliefs and practices, and partly due to perceptions or experiences of flying foxes as orchard pests. Indeed, the highest occurrence of $P$. vampyrus sightings now coincides with the durian flowering season in Sarawak, and the fruiting seasons of langsat, rambutan, and Syzygium cephalophorum. Similar trends in hunting pressure, trade and drivers were reported from Peninsular Malaysia, whereby it was predicted that legal hunting levels alone would lead to species extinction anytime between 6-81 years (Fujita 1988; Epstein et al. 2009; Cantlay et al. 2017).

\section{Trends in hunting and trade}

While the scale and intensity of flying fox hunting in western Sarawak do not seem as severe as that previously reported for Kalimantan (Indonesian Borneo; Struebig et al. 2007; Harrison et al. 2011) and Sulawesi (Sheherazade \& Tsang 2015), we believe this is likely because intense hunting pressure in the past has already caused drastic population reductions in Sarawak, pushing the species to more remote/inaccessible areas, and rendering it increasingly rare. The beliefs and practices reported in our study support those of other studies across Southeast Asia (Low et al. 2021).

Concurrently, this study also yielded qualitative details that helped to supplement empirical data. For example, during this survey we found that flying fox meat was not commonly seen in markets, but respondents reported it as being easily acquired at the Serian Wet Market. We did find P. vampyrus being sold openly at Pasar Tamu Sri Aman, despite hunting and selling of bats being illegal. A stall owner even commented that she could sell as many as 10-15 flying foxes in one single sale. Such information corroborates earlier surveys of wildlife meat availability by TRAFFIC Southeast Asia, that found flying fox meat still available for purchase at certain markets, restaurants and roadside stalls across Sarawak (K. Krishnasamy pers. comm.; Cantlay et al. 2017). This explains why the majority of our respondents felt that legal protection of $P$. vampyrus has not deterred or reduced hunting activity, as there was perceived to be a clear lack of enforcement.

One reason $P$. vampyrus is a highly valued wild meat amongst locals is the belief that it is a remedy for a variety of ailments and diseases, such as asthma, kidney ailments, gynaecological problems, and lung ailments 
(Mildenstein et al. 2016; Low et al. 2021). Flying fox liver and bile are also believed to cure asthma. One respondent even claimed that an alcoholic drink made by soaking an infant flying fox in 'langkau' (a particularly potent, locally brewed rice spirit) for a few weeks is an effective cure for asthma if consumed daily. Due to Islamic dietary restrictions, all Muslim respondents stated that it is forbidden for them to consume flying foxes. However, in Sebuyau, one Muslim respondent claimed that it is permissible to consume flying fox if this is done with the intent of curing illnesses, and not to consume it as a delicacy. This suggests that the perceived benefits of flying fox meat, which appears to be a widespread belief across their entire regional distribution (Mildenstein et al. 2016; Low et al. 2021), might be used by some as justification to override religious restrictions or aversions. Indeed, Harrison et al. (2011) reported similar attitudes in Indonesian Borneo, and cautioned that if this widely-held belief regarding health benefits is left unaddressed it would likely cause unsustainable hunting of flying foxes to continue. There is an urgent need to address this belief and practice by conducting community outreach and education for raising awareness, but also to implement targeted intervention strategies that leverage on social psychology approaches for incentivising behavioural change (Kingston 2016; St. John et al. 2018).

Worryingly, unlike in Indonesian Borneo (Harrison et al. 2011), more than half of the respondents did not feel that consumption of flying foxes had a negative impact on flying fox populations. The reason given was the belief that flying foxes breed rapidly, and therefore local hunting would not severely reduce populations, especially since hunting only occurs during the flowering and fruiting seasons. Indeed, almost $70 \%$ of the respondents stated that deforestation is a bigger threat due to it being the direct cause of flying fox habitat loss. Scientific research has shown that flying foxes actually have long lifespans and slow reproductive rates, so their populations would take a long time to recover from hunting pressure (Mildenstein et al. 2016). While Pteropus flying foxes are easily able to persist in humandominated areas with sufficient food resources (e.g., Tait et al. 2014; Aziz et al. 2017b), this proximity can render them more accessible and vulnerable to hunters (Chaiyes et al. 2017; Aziz et al. 2021). Also, low abundance of flying foxes can negatively affect their ecological roles, such as seed dispersal in forest ecosystems, long before these populations actually become extinct (McConkey \& Drake 2006; Luskin 2010). Therefore, we concur with Harrison et al. (2011) that overhunting remains the biggest threat to this species, and there is an urgent need to communicate such implications of intense or uncontrolled hunting pressure to local communities. Obtaining empirical long-term data on the hunting of flying foxes, and on the ecosystem services they provide, is necessary to ascertain whether current offtake levels are sustainable or not - not just in terms of population numbers, but also in terms of their ecological roles and the wider impact they have on ecosystem health.

\section{Negative interactions due to crop-raiding}

Loss (whether real or perceived) of fruits and flowers is clearly a major source of conflict between local fruit growers and flying foxes, and is also a factor driving the hunting of $P$. vampyrus in western Sarawak. Fruit growers stated that economic loss is their main motivation for killing $P$. vampyrus, as it is believed that eradication of this species can prevent such loss. Fruit growers at Pasar Tamu Sri Aman and Pasar Tani Lubok Antu even admitted to doing so despite stating that flying foxes foraging on their fruit trees would help disperse seeds to other areas. Flying foxes were still regarded as fruit pests even amongst fruit growers who acknowledged the bats' role as durian pollinators. This suggests that knowledge of flying fox ecosystem services alone is not enough to prevent killings, and therefore education and awareness-raising must be complemented by enforcement of regulations (e.g., see review by Aziz et al. 2016). Efforts are clearly needed to investigate and quantify fruit/flower losses attributed to P. vampyrus, and to trial non-lethal mitigation methods for protecting crops without killing or harming bats. These can be done following some of the potential methods reviewed and summarised by Aziz et al. (2016), but more recent studies have also been conducted for the Madagascan Flying Fox $P$. rufus and the Mauritian Flying Fox $P$. niger, whereby fruit loss from flying foxes was found to be minimal, and the use of organic deterrents, plastic flags, bells, and nylon net bags were found to be effective at reducing feeding in cultivated fruit trees (Raharimihaja et al. 2016; Oleksy et al. 2018; Tollington et al. 2019) .

\section{Support for flying fox conservation}

Finally, our survey uncovered some encouraging attitudes towards $P$. vampyrus: even though many respondents viewed flying foxes as pests and/or food, ecological and conservation awareness were relatively high, and there was grassroots-level support among some communities. Slightly more than half of our respondents, comprising hunters, consumers, and fruit growers, were willing to cooperate with wildlife agencies to protect $P$. 
vampyrus at the village level to prevent overhunting, as they still perceived flying foxes to be important for seed dispersal or tourism. The same number also agreed to participate in school events aimed at conserving flying foxes, as they believed these events are important for educating the younger generation on the importance of biodiversity conservation, and the ecosystem services provided by flying foxes. When asked further, these respondents mentioned that they were willing to attend conservation education programmes for communities in rural areas, such as talks or seminars on flying foxes. Those that strongly disagreed to participate in awareness programs stated that they didn't see the point of such efforts due to the fact that $P$. vampyrus numbers are now too low - suggesting that further efforts are needed to convince them that appropriate conservation interventions can indeed be effective. However, those that were unsure about participating said that they felt so because they were still unsure about the importance of flying foxes. This group of people clearly needs to be targeted as a priority audience for awareness and education campaigns.

Our results suggest that there is some support for flying fox conservation amongst local communities, as almost half of the respondents felt that $P$. vampyrus can be an iconic species for ecotourism, particularly if there are protected areas to safeguard populations. Those who disagreed provided mixed reasons; some stated that population numbers are so greatly reduced that it would be difficult to view the species in the wild, whereas others feared or viewed flying foxes as gruesome, and therefore did not see any ecotourism potential. Given that this species was traditionally respected and even revered in local Malaysian cultures (Low et al. 2021), it is unclear where such negative perceptions come from. As noted from other countries, properly managed and regulated bat tourism can indeed serve as an effective strategy for bat conservation (Pennisi et al. 2004; Aziz et al. 2017b; Tanalgo \& Hughes 2021). A sustained effort to revive positive local beliefs and imagery related to flying foxes, possibly in the form of Conservation Pride campaigns (Butler et al. 2013; de Pinho et al. 2014), could potentially help overcome such aversions by creating a mere-exposure effect (Zajonc 2001), hopefully predisposing both locals and tourists to start viewing bats positively.

\section{CAVEATS AND RECOMMENDATIONS}

Many of the respondents appeared to be candid in their comments, although on several occasions when they felt intimidated or suspected the enumerator to be a government official, they became very reluctant to provide details on the quantities and capture locations of flying foxes that were hunted and sold. Indeed, only $61.5 \%$ of the 200 people we approached agreed to be interviewed, and some who declined could have done so due to fear. As flying foxes are protected in Sarawak, hunting and consumption are illegal, and thus it is possible that some people did not want to participate in the survey because they feared their identity could be leaked to the authorities.

This underscores the difficulty of obtaining accurate data on flying fox hunting and trade, and highlights the need to employ more appropriate survey methods to reduce social desirability bias when asking sensitive questions that seek to understand illicit behaviour (Nuno \& St. John 2015; Mildenstein et al. 2016). A more suitable approach for wildlife conservation research, such as the unmatched count technique, should be explored in future work (Hinsley et al. 2019). Additionally, the current COVID-19 situation has introduced new complexities with regards to wildlife hunting and trade, as fears of disease risk could potentially reduce such activities (Low et al. 2021), but at the same time sensationalist media reports have increased negative perceptions of bats amongst the general public (Zhao 2020; Rocha et al. 2021). Since COVID-19 could potentially erode public support for bat conservation (Rocha et al. 2020), followup surveys are vital.

Although our results are preliminary, the information uncovered by our exploratory survey is a useful first step to provide a better understanding of the current situation, which will be important for guiding appropriate conservation strategies for the species and its habitats. We hope that both the quantitative and qualitative data yielded by this study will prove useful in helping to direct future efforts to conserve flying foxes in Sarawak, and also provide helpful insights for flying fox conservation efforts elsewhere.

\section{REFERENCES}

Altringham, J.D. (1996). Bats: Biology and Behaviour. Oxford University Press, New York, 262pp.

Aziz, S.A., K.R. McConkey, K. Tanalgo K., T. Sritongchuay, M-R. Low, J.Y. Yong, T.L. Mildenstein, C.E. Nuevo-Diego, V.C. Lim \& P.A. Racey (2021). The critical importance of Old World fruit bats for healthy 
ecosystems and economies. Frontiers in Ecology and Evolution 9: 641411. https://doi.org/10.3389/fevo.2021.641411

Aziz, S.A., K.J. Olival, S. Bumrungsri, G.C. Richards \& P.A. Racey (2016). The conflict between pteropodid bats and fruit growers: species, legislation and mitigation, pp. 377-426. In: Voigt, C.C. \& T. Kingston (eds). Bats in the Anthropocene: Conservation of Bats in a Changing World. SpringerOpen. https://doi.org/10.1007/978-3319-25220-9_13

Aziz, S.A., G.R. Clements, K.R. McConkey, T. Sritongchuay, S. Pathil, M.N.H. Abu Yazid, A. Campos-Arceiz, P-M. Forget \& S. Bumrungsri (2017a). Pollination by the locally endangered island flying fox (Pteropus hypomelanus) enhances fruit production of the economically important durian (Durio zibethinus). Ecology and Evolution 7(21): 8670-8684. https://doi.org/10.1002/ece3.3213

Aziz, S.A., G.R. Clements, X. Giam, P-M. Forget \& A. Campos-Arceiz (2017b). Coexistence and conflict between the Island Flying Fox (Pteropus hypomelanus) and humans on Tioman Island, Peninsular Malaysia. Human Ecology 45(3): 377-389. https://doig. org/10.1997/s10745-017-9905-6

Aziz, S.A., M-R. Low \& G.R. Clements (2019). A Conservation Roadmap for Flying Foxes Pteropus spp. in Peninsular Malaysia. Rimba, Kuala Lumpur, $40 \mathrm{pp}$

Bates, P., C. Francis, M. Gumal, S. Bumrungsri, J. Walston, L. Heaney \& T. Mildenstein (2008). Pteropus vampyrus. In: IUCN 2008. IUCN Red List of Threatened Species. Accessed on 24 November 2020. https:// doi.org/10.2305/IUCN.UK.2008.RLTS.T18766A8593657

Bumrungsri, S., E. Sripaoraya, T. Chongsiri, K. Sridith \& P.A. Racey (2009). The pollination ecology of durian (Durio zibethinus, Bombacaceae) in southern Thailand. Journal of Tropical Ecology 25(1): 85-92. https://doi.org/10.1017/S0266467408005531

Butler, P., K. Green \& D. Galvin (2013). The Principles of Pride: The Science Behind the Mascots. RARE, Arlington, $81 \mathrm{pp}$.

Cantlay, J.C., D.J. Ingram \& A.L. Meredith (2017). A review of zoonotic infection risks associated with the wild meat trade in Malaysia. EcoHealth 14(2): 361-388. https://doi.org/10.1007/ s10393-017-1229-x

Chaiyes, A., P. Duengkae, S. Wacharapluesadee, N. Pongpattananurak, K.J. Olival \& T. Hemachudha (2017). Assessing the distribution, roosting site characteristics, and population of Pteropus lylei in Thailand. Raffles Bulletin of Zoology 65: 670-680. http://zoobank. org/References/CD1BC57B-FA8A-4E1F-9A5C-E042659CB8C6

de Pinho, J. R., C. Grilo, R.B. Boone, K.A. Galvin \& J.G. Snodgrass (2014). Influence of Aesthetic Appreciation of Wildlife Species on Attitudes Towards their Conservation in Kenyan Agropastoralist Communities. PLOS ONE 9: e88842. https://doi.org/10.1371/ journal.pone.0088842

Department of Statistics Malaysia (2010). Population distributions and basic demographics characteristic. Retrieved on 24 November 2020 from: https://web.archive.org/web/20140522234002/http://www. statistics.gov.my/portal/download_Population/files/census2010/ Taburan_Penduduk_dan_Ciri-ciri_Asas_Demografi.pdf

Department of Statistics Malaysia (2019). Statistics Yearbook Sarawak. (Publication No. ISSN 0128-7613). Retrieved on 24 November 2020 from: https://newss.statistics.gov.my/newssportalx/ep/ epFreeDownloadContentSearch.seam?cid $=60237$

Epstein, J.H., K.J. Olival, J.R.C. Pulliam, C. Smith, J. Westrum, T. Hughes, A.P. Dobson, A. Zubaid, S.A. Rahman, M.M. Basir \& H.E. Field (2009). Pteropus vampyrus, a hunted migratory species with a multinational home-range and a need for regional management. Journal of Applied Ecology 46(5): 991-1002. https:// doi.org/10.1111/j.1365-2664.2009.01699.x

Fitzgibbon, S.I. \& D.N. Jones (2006). A community-based wildlife survey: The knowledge and attitudes of residents of suburban Brisbane, with a focus on bandicoots. Wildlife Research 33(3): 233. https://doi.org/1071/wr04029

Forest Department of Sarawak (2020). Facts and Figures. https:// forestry.sarawak.gov.my/page-0-0-1170-FACTS-FIGURES.html

Fujita, M. (1988). Flying foxes and economics. BATS 6(1): 4-9. https:// www.batcon.org/article/flying-foxes-and-economics/
Fujita, M.S. \& M.D. Tuttle (1991). Flying Foxes (Chiroptera: Pteropodidae): Threatened animals of key ecological and economic importance. Conservation Biology 5(4): 455-463. https://doi. org/10.1111/j.1523-1739.1991.tb00352.x

Gumal, M., S. Jamahari, M.I. Abdullah, C.J. Brandah, M.K. Abdullah \& A.R. Pawi (1997). The ecology and role of the large flying fox (Pteropus vampyrus) in Sarawakian rain forests. Hornbill 1: 32-47.

Gumal, M.T. (2001). Ecology and conservation of a fruit bat in Sarawak, Malaysia. PhD Thesis. Department of Anatomy, University of Cambridge, 234 pp.

Harrison, M.E., S.M. Cheyne, F. Darma, D.A. Ribowo, S.H. Limin \& M.J. Struebig (2011). Hunting of flying foxes and perception of disease risk in Indonesian Borneo. Biological Conservation 144(10): 2441-2449. https://doi.org/10.1016/j.biocon.2011.06.021

Hazebroek, H. P. \& A. M. Abang Kashim (2000). National Park of Sarawak. Kota Kinabalu: Natural History Publications (Borneo).

Hinsley, A., A. Keane, F.A.V. St. John, H. Ibbett \& A. Nuno (2019). Asking sensitive questions using the unmatched count technique: Applications and guidelines for conservation. Methods in Ecology and Evolution 10(3): 308-319. https://doi.org/10.1111/2041210X.13137

Kingston, T. (2016). Cute, creepy, or crispy - how values, attitudes, and norms shape human behavior towards bats, pp. 571-595. In: Voigt, C.C. \& T. Kingston (eds). Bats in the Anthropocene: Conservation of Bats in a Changing World. SpringerOpen. https:// doi.org/10.1007/978-3-319-25220-9_18

Kunz, T.H., E. Braun de Torrez, D. Bauer, T. Lobova T. \& T.H. Fleming (2011). Ecosystem services provided by bats. Annals of the New York Academy of Sciences 1223(1): 1-38. https://doi.10.1111/j.17496632.2011.06004.x

Low, M-R., Z.H. Wong, S. Shen, B. Murugavel, N. Mariner, L.M. Paguntalan, K. Tanalgo, M.M. Aung, Sheherazade, L.A. Bansa, T. Sritongchuay, J. Preble \& S.A. Aziz (2021). Bane or blessing? Reviewing cultural values of bats across the Asia-Pacific region. Journal of Ethnobiology41(1): 18-34. https://doi.org/10.2993/02780771-41.1.18

Luskin, M.S. (2010). Flying foxes prefer to forage in farmland in a tropical dry forest landscape mosaic in Fiji. Biotropica 42(2) 246250. https://doi.org/10.1111/j.1744-7429.2009.00577.x

McConkey, K.R. \& D.R. Drake (2006). Flying foxes cease to function as seed dispersers long before they become rare. Ecology 87(2): 271-276. https://doi.org/10.1890/05-0386

Mohd-Azlan, J., A. Zubaid \& T.H. Kunz (2001). Distribution, relative abundance and conservation status of large flying fox, Pteropus vampyrus in Peninsular Malaysia: A preliminary assessment. Acta Chiropterologica 3(2): 149-162.

Mohd-Azlan, J. \& M.F. Fauzi (2006). Ethnozoological survey in selected areas in Sarawak. Sarawak Museum Journal. LXII(83): 185-200.

Mildenstein, T., I. Tanshi \& P.A. Racey (2016). Exploitation of bats for bushmeat and medicine, pp. 325-375. In: Voigt, C.C. \& T. Kingston (eds). Bats in the Anthropocene: Conservation of Bats in a Changing World. SpringerOpen. https://doi.org/10.1007/978-3-319-252209_12

Nuno, A. \& F.A. St John (2015). How to ask sensitive questions in conservation: A review of specialized questioning techniques. Biological Conservation 189: 5-15. https://doi. org/10.1016/j.biocon.2014.09.047

Oleksy, R.Z., C.L. Ayady, V. Tatayah, C. Jones, J.S.P. Froidevaux, P.A. Racey \& G. Jones (2018). The impact of the endangered Mauritian flying fox Pteropus niger on commercial fruit farms and the efficacy of mitigation. Oryx 55(1): 114-121. https://doi.org/10.1017/ S0030605318001138

Pennisi, L.A., S.M. Holland \& T.V. Stein (2004). Achieving Bat Conservation Through Tourism. Journal of Ecotourism 3(3): 195207. https://doi.org/10.1080/14664200508668432

PERHILITAN (2017). Red List of Mammals for Peninsular Malaysia. Version 2.0. Department of Wildlife and National Parks Peninsular Malaysia (PERHILITAN), Kuala Lumpur, 206 pp.

Raharimihaja, T.E.A., J.L.M. Rakotoarison, P.A. Racey \& R.A. 
Andrianaivoarivelo (2016). A comparison of the effectiveness of methods of deterring pteropodid bats from feeding on commercial fruit in Madagascar. Journal of Threatened Taxa 8(13): 9512-9524. https://doi.org/10.11609/jott.2688.8.13.9512-9524

Rocha, R., S.A. Aziz, C.E. Brook, W.D. Carvalho,R. Cooper-Bohannon, W.F. Frick, J.C.-C. Huang, T. Kingston, A.L. López-Baucells, B. Maas, F. Mathews, R.A. Medellin, K.J. Olival, A.J. Peel, R.K. Plowright, O. Razgour, H. Rebelo, L. Rodrigues, S.J. Rossiter, D. Russo, T.M. Straka, E.C. Teeling, T. Treuer, C.C. Voigt \& P. Webala (2020). Bat conservation and zoonotic disease risk: a research agenda to prevent misguided persecution in the aftermath of COVID-19. Animal Conservation 24(3): 303-307. https://doi.org/10.1111/acv.12636

Rocha, R., A. López-Baucells \& Á. Fernández-Llamazares (2021). Ethnobiology of Bats: Exploring Human-Bat Inter-Relationships in a Rapidly Changing World. Journal of Ethnobiology 41(1): 3-17. https://doi.org/10.2993/0278-0771-41.1.3

Sheherazade \& S.M. Tsang (2015). Quantifying the bat bushmeat trade in North Sulawesi, Indonesia, with suggestions for conservation action. Global Ecology and Conservation 3: 324-330. https:// doi.org/10.1016/j.gecco.2015.01.003

Sheherazade, H.K. Ober \& S.M. Tsang (2019). Contributions of bats to the local economy through durian pollination in Sulawesi, Indonesia. Biotropica 51(6): 913-922. https://doi.org/10.1111/ btp.12712

St. John, F.A., M. Linkie, D.J. Martyr, B. Milliyanawati, J.E. McKay, F.M. Mangunjaya, N. LeaderWilliams \& M.J. Struebig (2018). Intention to kill: Tolerance and illegal persecution of Sumatran tigers and sympatric species. Conservation Letters 11(4): p.e12451. https://doi.org/10.1111/ conl.12451

Struebig, M.J., M.E. Harrison, S.M. Cheyne \& S.H. Limin (2007). Intensive hunting of large flying foxes Pteropus vampyrus natunae in Central Kalimantan, Indonesian Borneo. Oryx 41(3): 390393. https://doi/org/10.1017/S0030605307000310

Tait, J., H.L. Perotto-Baldivieso, A. McKeown \& D.A. Westcott (2014). Are flying-foxes coming to town? Urbanisation of the spectacled flying-fox (Pteropus conspicillatus) in Australia. PloS One 9 e109810. https://doi.org/10.1371/journal.pone.0109810

Tanalgo, K.C., R.D. Teves, F.R.P. Salvaña, R.E. Baleva \& J.A.G. Tabora (2016). Human-bat interactions in caves of South Central Mindanao, Philippines. Wildlife Biology in Practice 12(1): 1-14. https:// doi.org/10.2461/wbp.2016.12.2

Tanalgo, K. \& A.C. Hughes (2021). The potential of bat-watching tourism in raising public awareness towards bat conservation in the Philippines. Environmental Challenges 4: 100140. https://doi. org/10.1016/j.envc.2021.100140

Tollington, S., Z. Kareemun, A. Augustin, K. Lallchand, V. Tatayah, V. \& A. Zimmermann (2019). Quantifying the damage caused by fruit bats to backyard lychee trees in Mauritius and evaluating the benefits of protective netting. PLOS ONE 14: e0220955. https://doi.org/10.1371/journal. pone.0220955

Zajonc, R.B. (2001). Mere Exposure: A Gateway to the Subliminal. Current Directions in Psychological Sciences 10(6): 224-228. https://doi.org/10.1111/1467-8721.00154

Zhao, H. (2020). COVID-19 drives new threat to bats in China. Science 367(6485): 1436-1436. https://doi.org/ 10.1126/science.abb3088
Author details: Dr. Mohd-Azlan Jayasilan is an Associate Professor at the Institute of Biodiversity and Environmental Conservation, Universiti Malaysia Sarawak (UNIMAS). He conducts research on mammal ecology, threatened species, and protected areas. Mr. Yong Joon Yee is a Research Associate under Project Pteropus. He is also a student at the Department of Biological Sciences, Sunway University, Malaysia. He is pursuing his MSc on durian (Durio zibethinus) pollination networks across Peninsular Malaysia. Ms. Nabila Norshuhadah Mohd Hazzrol is a student at the Department of Zoology, Universiti Malaysia Sarawak (UNIMAS). She worked on ethnozoology for her undergraduate project. Ms. Philovenny Pengiran has a MSc from Universiti Malaysia Sarawak (UNIMAS). She does research on wildlife ecology and conservation. Her MSc focuses on the distribution, ecology and conservation of hornbills in western Sarawak. Ms. Arianti Atong is attached to the Visitors and Products Management Section of Sarawak Forestry Corporation, looking at the possibilities of flying foxes as an ecotourism product. Dr. Sheema Abdul Aziz is the cofounder \& President of Rimba, and Principal Investigator of Project Pteropus. Her work focuses on fruit bat conservation in Peninsular Malaysia through conducting research on batplant interactions and bat-human interactions, especially for flying foxes.

Author contributions: Jayasilan Mohd-Azlan conceived and designed the study, contributed materials, collected the data, wrote the paper, and reviewed drafts of the paper. Joon Yee Yong contributed analysis tools, prepared figures and/or tables, wrote the paper, and reviewed drafts of the paper. Nabila Norshuhadah Mohd Hazzrol collected the data, prepared figures and/or tables, and wrote the paper. Philovenny Pengiran collected the data, prepared figures and/or tables, and wrote the paper. Ariant Atong contributed to the concept and design of the study, and reviewed drafts of the paper. Sheema Abdul Aziz helped conceptualise the study, contributed analysis tools, prepared figures and/or tables, wrote the paper, and reviewed drafts of the paper.

Acknowledgements: We thank the Malaysian Ministry of Higher Education Fundamental Research Grant Scheme (FRGS/1/2020/WAB11/ UNIMAS/02/3) and the United States Fish and Wildlife Service (USFWS) for funding this research under the regional Southeast Asian Bat Conservation Research Unit (SEABCRU) project: 'Identifying and Addressing Factors Contributing to Flying Fox Trafficking in Southeast Asia' (F17AP00829), along with SEABCRU and Mabuwaya Foundation for coordinating the work under this grant. We are grateful to UNIMAS, Sarawak Forestry Corporation and Forest Department Sarawak (NPW.907.4.4(Id.14)-71 \& WL043/2017) for facilitating this project. We appreciate the assistance given by Ms. Shanaz Shamat and all the village heads during interviews, and the advice given by Tigga Kingston for study design. We are also indebted to Kanitha Krishnasamy and Serene Chng of TRAFFIC Southeast Asia, and Tom Hughes and Jimmy Lee of EcoHealth Alliance, for sharing further details and insights regarding the hunting, consumption and trade of flying foxes in Malaysia. Lastly, we are grateful to Gopalasamy Reuben Clements for providing technical advice and assistance. 
Supplementary Table 1. 'Flying Fox' in local Sarawakian languages.

\begin{tabular}{|l|l|}
\hline Ethnic group & Local names for flying foxes \\
\hline Iban & Entambah/Semawak \\
\hline Malay & Keluang \\
\hline Salako & Ka'uangk \\
\hline Bidayuh & Jingawat \\
\hline Melanau & Keluang/Nawai \\
\hline
\end{tabular}

Supplementary Table 2. Socio-demographic characteristics of respondents in the study area, western Sarawak, Malaysian Borneo.

\begin{tabular}{|c|c|c|}
\hline Characteristics & $\begin{array}{c}\text { Number of } \\
\text { Respondents }\end{array}$ & $\%$ \\
\hline \multicolumn{3}{|l|}{ Gender } \\
\hline Male & 83 & 68 \\
\hline Female & 40 & 32 \\
\hline \multicolumn{3}{|l|}{ Age range } \\
\hline$<21$ & 1 & 1 \\
\hline $22-34$ & 10 & 8 \\
\hline $35-44$ & 19 & 15 \\
\hline $45-54$ & 40 & 33 \\
\hline$\geq 55$ & 53 & 43 \\
\hline \multicolumn{3}{|l|}{ Religion } \\
\hline Christian & 74 & 60 \\
\hline Muslim & 37 & 30 \\
\hline Buddhist & 5 & 4 \\
\hline Atheist & 4 & 3 \\
\hline Taoist & 1 & 1 \\
\hline Bahai & 2 & 2 \\
\hline \multicolumn{3}{|l|}{ Ethnicity } \\
\hline Iban & 62 & 50 \\
\hline Malay & 26 & 21 \\
\hline Chinese & 7 & 6 \\
\hline Bidayuh & 8 & 7 \\
\hline Selako & 13 & 11 \\
\hline Melanau & 7 & 6 \\
\hline Others & 1 & 1 \\
\hline \multicolumn{3}{|l|}{ Working Sector } \\
\hline Unemployed & 26 & 21 \\
\hline Self-employed & 75 & 61 \\
\hline Employed in the government sector & 7 & 6 \\
\hline Employed in the private sector & 15 & 12 \\
\hline \multicolumn{3}{|l|}{ Income } \\
\hline$<$ RM999 & 85 & 69 \\
\hline RM1000-2499 & 32 & 26 \\
\hline RM2500-3500 & 4 & 3 \\
\hline$>$ RM10000 & 2 & 2 \\
\hline \multicolumn{3}{|l|}{ Residency Area } \\
\hline City & 1 & 1 \\
\hline Town & 16 & 13 \\
\hline Rural & 106 & 86 \\
\hline \multicolumn{3}{|l|}{ Education } \\
\hline No formal education & 34 & 28 \\
\hline Primary school & 33 & 27 \\
\hline Secondary school & 46 & 37 \\
\hline Post-school skill certificate & 5 & 4 \\
\hline Pre-university foundation course & 2 & 2 \\
\hline Diploma & 3 & 2 \\
\hline
\end{tabular}

Supplementary Table 3. P. vampyrus hunting activities in the study area, western Sarawak, Malaysian Borneo.

\begin{tabular}{|c|c|c|}
\hline Details & $\begin{array}{c}\text { Number of } \\
\text { Respondents }\end{array}$ & $\%$ \\
\hline \multicolumn{3}{|l|}{ Hunting experience } \\
\hline $\begin{array}{l}\text { Have more than a year of } \\
\text { experience }\end{array}$ & 24 & 100 \\
\hline \multicolumn{3}{|l|}{$\begin{array}{l}\text { Number of hunters in a } \\
\text { group }\end{array}$} \\
\hline 1-3 person/s & 10 & 42 \\
\hline 3-6 people & 10 & 42 \\
\hline 6-9 people & 2 & 8 \\
\hline 9-12 people & 1 & 4 \\
\hline$>12$ & 1 & 4 \\
\hline \multicolumn{3}{|l|}{ Time of the hunt } \\
\hline 0600hrs-0900hrs & 2 & 8 \\
\hline $1800 \mathrm{hrs}-2100 \mathrm{hrs}$ & 8 & 34 \\
\hline $2100 \mathrm{hrs}-0000 \mathrm{hrs}$ & 12 & 50 \\
\hline 0000hrs-0300hrs & 1 & 4 \\
\hline 0300hrs-0600hrs & 1 & 4 \\
\hline \multicolumn{3}{|l|}{ Hunting area } \\
\hline Swamp area & 1 & 4 \\
\hline Forest edge & 5 & 21 \\
\hline Fruit orchard & 18 & 75 \\
\hline \multicolumn{3}{|l|}{ Transportation } \\
\hline Car & 1 & 4 \\
\hline Motorcycle & 7 & 29 \\
\hline On foot & 16 & 67 \\
\hline \multicolumn{3}{|l|}{ Hunting Method } \\
\hline Net techniques & 6 & 25 \\
\hline Shot gun & 11 & 46 \\
\hline Traditional methods & 7 & 29 \\
\hline \multicolumn{3}{|l|}{ Cost of hunting tools } \\
\hline$<$ MYR 50 & 16 & 67 \\
\hline MYR 51-100 & 5 & 21 \\
\hline MYR 101-300 & 3 & 12 \\
\hline \multicolumn{3}{|l|}{$\begin{array}{l}\text { Average number of } \\
\text { individual bats caught }\end{array}$} \\
\hline$\leq 10$ & 16 & 67 \\
\hline $11-20$ & 6 & 25 \\
\hline $21-40$ & 2 & 8 \\
\hline \multicolumn{3}{|l|}{ Hunting purpose } \\
\hline Food & 13 & 54 \\
\hline Pest & 9 & 38 \\
\hline Source of income & 2 & 8 \\
\hline
\end{tabular}



Dr. John Noyes, Natural History Museum, London, UK

Dr. Albert G. Orr, Griffith University, Nathan, Australia

Dr. Sameer Padhye, Katholieke Universiteit Leuven, Belgium

Dr. Nancy van der Poorten, Toronto, Canada

Dr. Kareen Schnabel, NIWA, Wellington, New Zealand

Dr. R.M. Sharma, (Retd.) Scientist, Zoological Survey of India, Pune, India

Dr. Manju Siliwal, WILD, Coimbatore, Tamil Nadu, India

Dr. G.P. Sinha, Botanical Survey of India, Allahabad, India

Dr. K.A. Subramanian, Zoological Survey of India, New Alipore, Kolkata, India

Dr. P.M. Sureshan, Zoological Survey of India, Kozhikode, Kerala, India

Dr. R. Varatharajan, Manipur University, Imphal, Manipur, India

Dr. Eduard Vives, Museu de Ciències Naturals de Barcelona, Terrassa, Spain

Dr. James Young, Hong Kong Lepidopterists' Society, Hong Kong

Dr. R. Sundararaj, Institute of Wood Science \& Technology, Bengaluru, India

Dr. M. Nithyanandan, Environmental Department, La Ala Al Kuwait Real Estate. Co. K.S.C.,

Kuwait

Dr. Himender Bharti, Punjabi University, Punjab, India

Mr. Purnendu Roy, London, UK

Dr. Saito Motoki, The Butterfly Society of Japan, Tokyo, Japan

Dr. Sanjay Sondhi, TITLI TRUST, Kalpavriksh, Dehradun, India

Dr. Nguyen Thi Phuong Lien, Vietnam Academy of Science and Technology, Hanoi, Vietnam

Dr. Nitin Kulkarni, Tropical Research Institute, Jabalpur, India

Dr. Robin Wen Jiang Ngiam, National Parks Board, Singapore

Dr. Lional Monod, Natural History Museum of Geneva, Genève, Switzerland.

Dr. Asheesh Shivam, Nehru Gram Bharti University, Allahabad, India

Dr. Rosana Moreira da Rocha, Universidade Federal do Paraná, Curitiba, Brasi

Dr. Kurt R. Arnold, North Dakota State University, Saxony, Germany

Dr. James M. Carpenter, American Museum of Natural History, New York, USA

Dr. David M. Claborn, Missouri State University, Springfield, USA

Dr. Kareen Schnabel, Marine Biologist, Wellington, New Zealand

Dr. Amazonas Chagas Júnior, Universidade Federal de Mato Grosso, Cuiabá, Brasil

Mr. Monsoon Jyoti Gogoi, Assam University, Silchar, Assam, India

Dr. Heo Chong Chin, Universiti Teknologi MARA (UiTM), Selangor, Malaysia

Dr. R.J. Shiel, University of Adelaide, SA 5005, Australia

Dr. Siddharth Kulkarni, The George Washington University, Washington, USA

Dr. Priyadarsanan Dharma Rajan, ATREE, Bengaluru, India

Dr. Phil Alderslade, CSIRO Marine And Atmospheric Research, Hobart, Australia

Dr. John E.N. Veron, Coral Reef Research, Townsville, Australia

Dr. Daniel Whitmore, State Museum of Natural History Stuttgart, Rosenstein, Germany.

Dr. Yu-Feng Hsu, National Taiwan Normal University, Taipei City, Taiwan

Dr. Keith V. Wolfe, Antioch, California, USA

Dr. Siddharth Kulkarni, The Hormiga Lab, The George Washington University, Washington,

D.C., USA

Dr. Tomas Ditrich, Faculty of Education, University of South Bohemia in Ceske

Budejovice, Czech Republic

Dr. Mihaly Foldvari, Natural History Museum, University of Oslo, Norway

Dr. V.P. Uniyal, Wildlife Institute of India, Dehradun, Uttarakhand 248001, India

Dr. John T.D. Caleb, Zoological Survey of India, Kolkata, West Bengal, India

Dr. Priyadarsanan Dharma Rajan, Ashoka Trust for Research in Ecology and the Environment

(ATREE), Royal Enclave, Bangalore, Karnataka, India

\section{Fishes}

Dr. Neelesh Dahanukar, IISER, Pune, Maharashtra, India

Dr. Topiltzin Contreras MacBeath, Universidad Autónoma del estado de Morelos, México

Dr. Heok Hee Ng, National University of Singapore, Science Drive, Singapore

Dr. Rajeev Raghavan, St. Albert's College, Kochi, Kerala, India

Dr. Robert D. Sluka, Chiltern Gateway Project, A Rocha UK, Southall, Middlesex, UK

Dr. E. Vivekanandan, Central Marine Fisheries Research Institute, Chennai, India

Dr. Davor Zanella, University of Zagreb, Zagreb, Croatia

Dr. A. Biju Kumar, University of Kerala, Thiruvananthapuram, Kerala, India

Dr. Akhilesh K.V., ICAR-Central Marine Fisheries Research Institute, Mumbai Research

Centre, Mumbai, Maharashtra, India

Dr. J.A. Johnson, Wildlife Institute of India, Dehradun, Uttarakhand, India

Amphibians

Dr. Sushil K. Dutta, Indian Institute of Science, Bengaluru, Karnataka, India

Dr. Annemarie Ohler, Muséum national d'Histoire naturelle, Paris, France

\section{Reptiles}

Dr. Gernot Vogel, Heidelberg, Germany

Dr. Raju Vyas, Vadodara, Gujarat, India

Dr. Pritpal S. Soorae, Environment Agency, Abu Dubai, UAE.

Prof. Dr. Wayne J. Fuller, Near East University, Mersin, Turkey

Prof. Chandrashekher U. Rivonker, Goa University, Taleigao Plateau, Goa. India

Dr. S.R. Ganesh, Chennai Snake Park, Chennai, Tamil Nadu, India

Dr. Himansu Sekhar Das, Terrestrial \& Marine Biodiversity, Abu Dhabi, UAE
Birds

Dr. Hem Sagar Baral, Charles Sturt University, NSW Australia

Dr. Chris Bowden, Royal Society for the Protection of Birds, Sandy, UK

Dr. Priya Davidar, Pondicherry University, Kalapet, Puducherry, India

Dr. J.W. Duckworth, IUCN SSC, Bath, UK

Dr. Rajah Jayapal, SACON, Coimbatore, Tamil Nadu, India

Dr. Rajiv S. Kalsi, M.L.N. College, Yamuna Nagar, Haryana, India

Dr. V. Santharam, Rishi Valley Education Centre, Chittoor Dt., Andhra Pradesh, India

Dr. S. Balachandran, Bombay Natural History Society, Mumbai, India

Mr. J. Praveen, Bengaluru, India

Dr. C. Srinivasulu, Osmania University, Hyderabad, India

Dr. K.S. Gopi Sundar, International Crane Foundation, Baraboo, USA

Dr. Gombobaatar Sundev, Professor of Ornithology, Ulaanbaatar, Mongolia

Prof. Reuven Yosef, International Birding \& Research Centre, Eilat, Israel

Dr. Taej Mundkur, Wetlands International, Wageningen, The Netherlands

Dr. Carol Inskipp, Bishop Auckland Co., Durham, UK

Dr. Tim Inskipp, Bishop Auckland Co, Durham, UK

Dr. V. Gokula, National College, Tiruchirappalli, Tamil Nadu, India

Dr. Arkady Lelej, Russian Academy of Sciences, Vladivostok, Russia

Dr. Simon Dowell, Science Director, Chester Zoo, UK

Dr. Mário Gabriel Santiago dos Santos, Universidade de Trás-os-Montes e Alto Douro,

Quinta de Prados, Vila Real, Portugal

Dr. Grant Connette, Smithsonian Institution, Royal, VA, USA

Dr. M. Zafar-ul Islam, Prince Saud Al Faisal Wildlife Research Center, Taif, Saudi Arabia

Mammals

Dr. Giovanni Amori, CNR - Institute of Ecosystem Studies, Rome, Italy

Dr. Anwaruddin Chowdhury, Guwahati, India

Dr. David Mallon, Zoological Society of London, UK

Dr. Shomita Mukherjee, SACON, Coimbatore, Tamil Nadu, India

Dr. Angie Appel, Wild Cat Network, Germany

Dr. P.O. Nameer, Kerala Agricultural University, Thrissur, Kerala, India

Dr. Ian Redmond, UNEP Convention on Migratory Species, Lansdown, UK

Dr. Heidi S. Riddle, Riddle's Elephant and Wildlife Sanctuary, Arkansas, USA

Dr. Karin Schwartz, George Mason University, Fairfax, Virginia.

Dr. Lala A.K. Singh, Bhubaneswar, Orissa, India

Dr. Mewa Singh, Mysore University, Mysore, India

Dr. Paul Racey, University of Exeter, Devon, UK

Dr. Honnavalli N. Kumara, SACON, Anaikatty P.O., Coimbatore, Tamil Nadu, India

Dr. Nishith Dharaiya, HNG University, Patan, Gujarat, India

Dr. Spartaco Gippoliti, Socio Onorario Società Italiana per la Storia della Fauna "Giuseppe

Altobello", Rome, Italy

Dr. Justus Joshua, Green Future Foundation, Tiruchirapalli, Tamil Nadu, India

Dr. H. Raghuram, The American College, Madurai, Tamil Nadu, India

Dr. Paul Bates, Harison Institute, Kent, UK

Dr. Jim Sanderson, Small Wild Cat Conservation Foundation, Hartford, USA

Dr. Dan Challender, University of Kent, Canterbury, UK

Dr. David Mallon, Manchester Metropolitan University, Derbyshire, UK

Dr. Brian L. Cypher, California State University-Stanislaus, Bakersfield, CA

Dr. S.S. Talmale, Zoological Survey of India, Pune, Maharashtra, India

Prof. Karan Bahadur Shah, Budhanilakantha Municipality, Kathmandu, Nepal

Dr. Susan Cheyne, Borneo Nature Foundation International, Palangkaraja, Indonesia

Dr. Hemanta Kafley, Wildlife Sciences, Tarleton State University, Texas, USA

\section{Other Disciplines}

Dr. Aniruddha Belsare, Columbia MO 65203, USA (Veterinary)

Dr. Mandar S. Paingankar, University of Pune, Pune, Maharashtra, India (Molecular)

Dr. Jack Tordoff, Critical Ecosystem Partnership Fund, Arlington, USA (Communities)

Dr. Ulrike Streicher, University of Oregon, Eugene, USA (Veterinary)

Dr. Hari Balasubramanian, EcoAdvisors, Nova Scotia, Canada (Communities)

Dr. Rayanna Hellem Santos Bezerra, Universidade Federal de Sergipe, São Cristóvão, Brazil

Dr. Jamie R. Wood, Landcare Research, Canterbury, New Zealand

Dr. Wendy Collinson-Jonker, Endangered Wildlife Trust, Gauteng, South Africa

Dr. Rajeshkumar G. Jani, Anand Agricultural University, Anand, Gujarat, India

Dr. O.N. Tiwari, Senior Scientist, ICAR-Indian Agricultural Research Institute (IARI), New

Delhi, India

Dr. L.D. Singla, Guru Angad Dev Veterinary and Animal Sciences University, Ludhiana, India

Dr. Rupika S. Rajakaruna, University of Peradeniya, Peradeniya, Sri Lanka

Dr. Bahar Baviskar, Wild-CER, Nagpur, Maharashtra 440013, India

Reviewers 2018-2020

Due to pausity of space, the list of reviewers for $2018-2020$ is available online.

The opinions expressed by the authors do not reflect the views of the Journal of Threatened Taxa, Wildlife Information Liaison Development Society, Zoo Outreach Organization, or any of the partners. The journal, the publisher, the host, and the partners are not responsible for the accuracy of the political boundaries shown in the maps by the authors.

Journal of Threatened Taxa is indexed/abstracted in Bibliography of Systematic Mycology, Biological Abstracts, BIOSIS Previews, CAB Abstracts, EBSCO, Google Scholar, Index Copernicus, Index Fungorum, JournalSeek, National Academy of Agricultural Sciences, NewJour, OCLC WorldCat, SCOPUS, Stanford University Libraries, Virtual Library of Biology, Zoological Records.

NAAS rating (India) 5.64
Print copies of the Journal are available at cost. Write to:

The Managing Editor, JoTT,

c/o Wildlife Information Liaison Development Society,

No. 12, Thiruvannamalai Nagar, Saravanampatti - Kalapatti Road,

Saravanampatti, Coimbatore, Tamil Nadu 641035, India

ravi@threatenedtaxa.org 


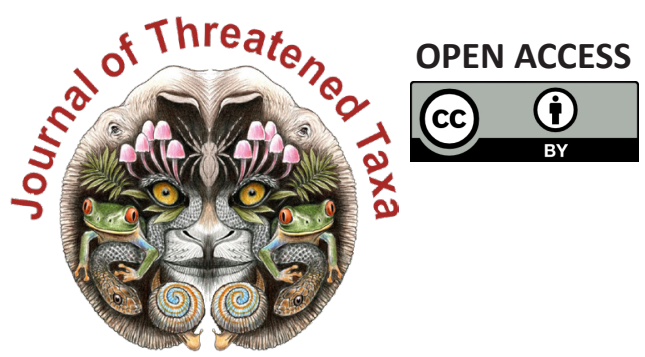

www.threatenedtaxa.org

The Journal of Threatened Taxa (JoTT) is dedicated to building evidence for conservation globally by publishing peer-reviewed articles online every month at a reasonably rapid rate at www.threatenedtaxa.org. All articles published in JoTT are registered under Creative Commons Attribution 4.0 International License unless otherwise mentioned. JoTT allows allows unrestricted use, reproduction, and distribution of articles in any medium by providing adequate credit to the author(s) and the source of publication.

\section{ISSN $0974-7907$ (Online) | ISSN $0974-7893$ (Print)}

\section{January 2022 | Vol. 14 | No. 1 | Pages: 20311-20538 \\ Date of Publication: 26 January 2022 (Online \& Print) DOI: 10.11609/jott.2022.14.1.20311-20538}

Articles

Estimating the completeness of orchid checklists and atlases: a case study from southern Italy

- Antonio Croce, Pp. 20311-20322

A floristic survey across three coniferous forests of Kashmir Himalaya, India - a checklist

- Ashaq Ahmad Dar, Akhtar Hussain Malik \& Narayanaswamy Parthasarathy, Pp. 20323-20345

Associations of butterflies across different forest types in Uttarakhand, western Himalaya, India: implications for conservation planning

- Arun Pratap Singh, Pp. 20346-20370

Comparison of bird diversity in protected and non-protected wetlands of western lowland of Nepal

- Jagan Nath Adhikari, Janak Raj Khatiwada, Dipendra Adhikari, Suman Sapkota, Bishnu Prasad Bhattarai, Deepak Rijal \& Lila Nath Sharma, Pp. 20371-20386

Local hunting practices and perceptions regarding the distribution and ecological role of the Large Flying Fox (Chiroptera: Pteropodidae: Pteropus vampyrus) in western Sarawak, Malaysian Borneo

- Jayasilan Mohd-Azlan, Joon Yee Yong, Nabila Norshuhadah Mohd Hazzrol, Philovenny Pengiran, Arianti Atong \& Sheema Abdul Aziz, Pp. 20387-20399

\section{Communications}

Macrolichens of Mathikettan Shola National Park, Western Ghats: a preliminary investigation with some new records

- Aswathi Anilkumar, Stephen Sequeira, Arun Christy \& S.M. Arsha, Pp. 20400-20405

New distribution record of globally threatened Ocean Turf Grass Halophila beccarii Ascherson, 1871 from the North Andaman Islands highlights the importance of seagrass exploratory surveys

- Swapnali Gole, Prasad Gaidhani, Srabani Bose, Anant Pande, Jeyaraj Antony Johnson \& Kuppusamy Sivakumar, Pp. 20406-20412

An inventory of new orchid (Orchidaceae) records from Kozhikode, Kerala, India - M. Sulaiman, C. Murugan \& M.U. Sharief, Pp. 20413-20425

Abundance and spatial distribution analyses of Stemonoporus moonii Thwaites (Dipterocarpaceae) - a critically endangered species endemic to Sri Lanka - K.A.M.R.P. Atapattu, H.D.D.C.K. Perera, H.S. Kathriarachchi \& A.R. Gunawardena, Pp. 20426-20432

Plant diversity of Point Calimere Wildlife Sanctuary and fodder species grazed by the Blackbuck Antilope cervicapra L.

- Ashutosh Kumar Upadhyay, A. Andrew Emmanuel, Ansa Sarah Varghese \&

D. Narasimhan, Pp. 20433-20443

Raptors observed (1983-2016) in National Chambal Gharial Sanctuary: semi-arid biogeographic region suggestions for parametric studies on ecological continuity in Khathiar-Gir Ecoregion, India

- L.A.K. Singh, R.K. Sharma \& Udayan Rao Pawar, Pp. 20444-20460

Nesting success of Sharpe's Longclaw (Macronyx sharpei Jackson, 1904) around the grasslands of lake Ol'bolossat Nyandarua, Kenya

- Hamisi Ann Risper, Charles M. Warui \& Peter Njoroge, Pp. 20461-20468

Population, distribution and diet composition of Smooth-coated Otter Lutrogale perspicillata Geoffroy, 1826 in Hosur and Dharmapuri Forest Divisions, India - Nagarajan Baskaran, Raman Sivaraj Sundarraj \& Raveendranathanpillai Sanil, Pp. 20469-20477

Utilization of home garden crops by primates and current status of human-primate interface at Galigamuwa Divisional Secretariat Division in Kegalle District, Sri Lanka

- Charmalie Anuradhie Dona Nahallage, Dahanakge Ayesha Madushani Dasanayake, Dilan Thisaru Hewamanna \& Dissanayakalage Tharaka Harshani Ananda, Pp. 2047820487
Revival of Eastern Swamp Deer Rucervus duvaucelii ranjitsinhi (Groves, 1982) in Manas National Park of Assam, India

- Nazrul Islam, Aftab Ahmed, Rathin Barman, Sanatan Deka, Bhaskar Choudhury, Prasanta Kumar Saikia \& Jyotishman Deka, Pp. 20488-20493

Trypanosoma evansi infection in a captive Indian Wolf Canis lupus pallipes - molecular diagnosis and therapy

- Manojita Dash, Sarat Kumar Sahu, Santosh Kumar Gupta, Niranjana Sahoo \& Debarat Mohapatra, Pp. 20494-20499

View Point

COVID-19 and civil unrest undoing steady gains in karst conservation and herpetological research in Myanmar, and an impediment to progress - Evan S.H. Quah, Lee L. Grismer, Perry L. Wood, Jr., Aung Lin \& Myint Kyaw Thura, Pp. 20500-20502

\section{Short Communications}

Morphological characterization and mt DNA barcode of a tiger moth species, Asota ficus (Fabricius, 1775) (Lepidoptera: Noctuoidea: Erebidae: Aganainae) from India - Aparna Sureshchandra Kalawate, K.P. Dinesh \& A. Shabnam, Pp. 20503-20510

Distribution of Smooth-coated Otters Lutrogale perspicillata (Mammalia: Carnivora: Mustelidae): in Ratnagiri, Maharashtra, India

- Swanand Patil \& Kranti Yardi, Pp. 20511-20516

Wildlife at the crossroads: wild animal road kills due to vehicular collision on a mountainous highway in northwestern Himalayan region

- Muzaffar A. Kichloo, Asha Sohil \& Neeraj Sharma, Pp. 20517-20522

Notes

Robiquetia gracilis (Lindl.) Garay-a new record to the flora of Anamalai Hills, Tami Nadu, India

- B. Subbaiyan, V. Ganesan, P.R. Nimal Kumar \& S. Thangaraj Panneerselvam, Pp. 20523-20525

Ipomoea laxiflora H.J. Chowdhery \& Debta (Convolvulaceae): new records for the Western Ghats and semiarid regions

- Sachin M. Patil, Ajit M. Vasava, Vinay M. Raole \& Kishore S. Rajput, Pp. 20526-20529

Counting the cost: high demand puts Bunium persicum (Boiss.) B.Fedtsch. in jeopardy

- Monika Sharma, Manisha Mathela, Rupali Sharma, Himanshu Bargali, Gurinderjit S Goraya \& Amit Kumar, Pp. 20530-20533

First record of Parasitic Jaeger Stercorarius parasiticus (Aves: Charadriiformes: Stercorariidae) from inland freshwater Inle Lake, Myanmar

- Sai Sein Lin Oo, Myint Kyaw, L.C.K. Yun, Min Zaw Tun, Yar Zar Lay Naung, Soe Naing Aye \& Swen C. Renner, Pp. 20534-20536

\section{Book Review}

Capparis of India

- V. Sampath Kumar, Pp. 20537-20538
Publisher \& Host
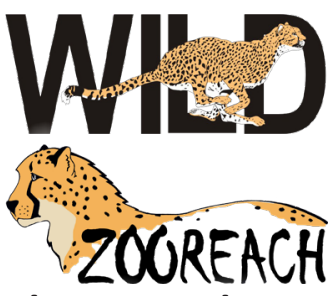

Threatened Taxa 